\title{
AFRO-AMERICAN HEPATICS REVISITED
}

\author{
S. ROBBERT GRADSTEIN
}

\begin{abstract}
In 1983, Gradstein, Pócs and Váňa discussed the disjunct Afro-American ranges of 41 liverwort species and 8 genera. Since the appearance of this paper much progress has been made in the study of tropical liverworts and knowledge of the neotropical and African floras has improved considerably. The new investigations have raised the number of Afro-American hepatics to 74 species, 13 genera and one family (Oxymitraceae). Afro-American species constitute about 5\% of the neotropical liverwort flora and $8 \%$ of the flora of Africa. The percentages of species shared by the two continents are doubled when pantropical species are added. Five Afro-American species are newly recognized in this paper: Calypogeia peruviana Nees \& Mont. (= C. afrocaerulea E. W. Jones, syn. nov.), Ceratolejeunea coarina (Gottsche) Steph. (= C. diversicornua Steph., syn. nov.), C. ornithocephala Herzog (=C. kilimanjarica Pócs \& Ast, syn. nov.), Odontoschisma variabile (Lindenb. \& Gottsche) Trevis. (= O. africanum Steph., syn. nov.) and Syzygiella manca (Mont.) Steph. [= S. geminifolia (Mitt.) Steph., syn. nov.]. Spore dispersal experiments and molecular-phylogenetic studies have shown that the intercontinental ranges of liverwort species, and of the majority of genera, should have resulted from long-distance dispersal events, not from vicariance.
\end{abstract}

Key words: Afro-American, Afro-Asiatic, disjunct distribution, dispersal, elevational range, intercontinental range, liverworts, long-distance dispersal, pantropical, spore viability, tropical rainforest

S. Robbert Gradstein, Muséum National d'Histoire Naturelle, Department Systématique et Evolution, C.P. 39 , 57 rue Cuvier, 75231 Paris cedex 05, France, gradstein@mnhn.fr

\section{INTRODUCTION}

In 1983, Tamás Pócs, Jiří Váňa and I reviewed the disjunct distributions of liverwort species and genera occurring in tropical America and Africa, and not or very restrictedly occurring elsewhere (Gradstein et al. 1983). The study was instigated by the increasingly large number of Afro-American taxa that were emerging from taxonomic and floristic studies on tropical hepatics. We were able to recognize disjunct Afro-American ranges in 41 species and 8 genera of liverworts; some of the ranges included W Europa and India as well. Most taxa were members of the leafy Jungermanniidae; a few subtropical species were thalloid. Lowland species usually had more or less continuous distributions on each continent whereas montane and alpine taxa had more dissected ranges due to the more scattered distribution of high-elevation habitats. We also documented the ranges of 25 putative Afro-American species pairs, consisting of morphologically and ecologically closely similar species from Africa and tropical
America that had been little studied and might turn out to be conspecific. Based on a scrutiny of the reproductive features (sexuality, fertility, spore size, availability of asexual propagules) of the Afro-American taxa, we concluded that the transoceanic ranges of the species had probably arisen by successful long-distance dispersal events (LDD) across the Atlantic. For Afro-American genera and species pairs, a possible origin of the intercontinental ranges due to vicariance, viz. via ancient land connections, was suggested.

Since the appearance of our paper, much progress has been made in the study of tropical hepatics. Numerous floristic studies were undertaken in the two continents, in Africa notably by E. W. Jones, T. Pócs, M. Wigginton and others, in the Neotropics by the author and his students, A. Schäfer-Verwimp and many others. As a result, our knowledge of the Neotropical and African liverwort floras has improved considerably. In 1983, identification manuals were available for 
the liverworts of S Africa and southern Congo (Arnell 1963; Vanden Berghen 1972) but none for tropical America (the manual for Latin American liverworts by Fulford 1963-1976 remained very incomplete), and up-to-date checklists were very few (Gradstein \& Hekking 1979; Gradstein \& Weber 1982; Grolle 1978). Now, 30 years later, identification manuals are available for W Africa, S Africa, Kenya, Brazil and French Guiana, and modern checklists for the whole of tropical Africa and numerous neotropical countries, e.g. Belize, Costa Rica, Panama, Jamaica, Guadeloupe, Dominica, Martinique, Guianas, Brazil, Colombia, Ecuador and Bolivia (Chuah-Petiot 2003; Churchill et al. 2009; Dauphin 2005; Gradstein 1997; Gradstein \& Costa 2003; Gradstein et al. 2003; Gradstein \& Ilkiu-Borges 2009; Gradstein \& Uribe in press; Lavocat \& Schäfer-Verwimp 2011; Léon-Yánez et al. 2006; Schäfer-Verwimp 2009; Söderström et al. 2011; Stotler et al. 1996; Wigginton 2004, 2009; Whittemore \& Allen 1996). New revisions and monographs have also become available although their total number is still limited (e.g., Gradstein 1985; van Slageren 1985; Kruijt 1988; Yuzawa 1991; Gradstein 1994; He 1999; Reiner-Drehwald \& Goda 2000; Heinrichs 2002; Dauphin 2003; Bischler et al. 2005; So 2005; Ilkiu-Borges 2006; Burghardt \& Gradstein 2008; Costa 2008).

Our understanding of the causes of the AfroAmerican liverwort ranges has significantly improved since 1983 by spore viability tests and, more recently, based on molecular work. Van Zanten and Gradstein (1988) tested the spore viability of a suite of endemic and widespread tropical liverwort species, including 13 Afro-American taxa (Table 1), by means of spore germination experiments and analysis of a various reproductive traits. They found that spores of widespread species were significantly more durable and more suited to LDD than those of endemic species. Bisexuality and dark colour of spores were also advantageous for LDD, but other traits such as spore size and endosporous vs exosporous germination ('green' vs 'non-green' spores) were not. The authors also tested the impact of UV radiation on spore viability by flying spores across the Atlantic on the wings of a commercial jumbo-jet aeroplane and found that UV was lethal in most species, except in a few from high alpine environments. The experiments confirmed that the ranges of the intercontinentally distributed species could have resulted from LDD. Based on the results of the UV tests, the authors concluded that successful dispersal events across the Atlantic should have occurred via moist air currents at rather low elevations, not via the dry jet streams at high elevation.

In a few instances the results of the experiments conflicted with the known ranges of the species. The spores of the Afro-American Riccardia amazonica proved to be unsuited for LDD, having lost their capability of germination after a few hours of desiccation. Those of Marchesinia brachiata, on the other hand, retained their capacity for germination for several weeks after desiccation and seemed quite well suited for LDD even though the species was at that time not known outside tropical America. Recent studies, however, have revealed the occurrence of Marchesinia brachiata in Africa (Heinrichs et al. 2009). This shows that spore viability tests may be a powerful tool for predicting the true ranges of tropical liverwort species.

Van Zanten and Gradstein (1988) also compared the range sizes with the habitats of the species and found that intercontinental ranges were particularly common among xerophytes, among lowland species and among species from the canopy of the rain forest. The prevalence of transoceanic ranges among canopy epiphytes was subsequently confirmed by He (1999) for Pycnolejeunea and by Gradstein (2006) in a study on the lowland cloud forest of French Guiana.

Modern molecular-phylogenetic work has allowed for testing the monophyly of intercontinentally distributed species and for detecting new transoceanic ranges. The studies also allowed for scrutinizing the dispersal and vicariance hypotheses by adding an estimated time scale to the phylogeny, based on fossils (when available) and putative DNA mutation rates (Renner 2005). The molecular studies confirmed the Afro-American range of 14 liverwort species (Table 1), including, e.g., Symphyogyna podophylla (Schaumann et al. 2003), various Plagiochila species (Heinrichs et al. 
2004, 2005a,b; Lindner et al. 2004), Tylimanthus laxus (Stech et al. 2006), Herbertus juniperoides (Feldberg et al. 2007), Porella swartziana (Hentschel et al. 2007), Leptoscyphus cuneifolius (Devos \& Vanderpoorten 2009), Marchesinia brachiata (Heinrichs et al. 2009), Syzygiella concreta (Feldberg et al. 2011), etc. The molecular clock data strongly supported the LDD hypothesis. They showed that the Afro-American liverwort taxa were generally too young for a vicariance scenario of evolution. In almost all cases a Gondwanan origin could be rejected, at the species as well as at the generic level. Instead, the intercontinental ranges were explained by LDD followed by short distance overland dispersal and evolutionary diversification (Heinrichs et al. 2009; Devos \& Vanderpoorten 2009; Vanderpoorten et al. 2009). In some cases the molecular studies allowed for constructing migration scenarios. For two Afro-American species of Plagiochila (P. boryana, P. corrugata) a neotropical origin of the African populations seemed likely (Heinrichs et al. 2005b); in other cases, however, the molecular data were inconclusive for determining the geographical origin of species. In general, the reconstruction of the past migration routes of liverworts is hampered by the poor fossil record and the lack of dated phylogenies.

\section{AFRO-AMERICAN HEPATICS - AN UPDATED OVERVIEW}

1. SPECIES (Tables 1, 2; see also NOTES ON Afro-AmericAn SPECIES). Among the AfroAmerican liverwort species listed by Gradstein et al. (1983), nine have since been shown to possess wider or narrower ranges and are excluded from the list: Aphanolejeunea exigua, Brachiolejeunea laxifolia, Chiloscyphus vermicularis (= Clasmatocolea vermicularis), Cololejeunea cardiocarpa, Herbertus subdentatus, Heteroscyphus integrifolius, Microlejeunea ulicina, Pycnolejeunea contigua and Radula boryana (see below: Excluded species). On the other hand, 42 AfroAmerican species have been added since 1983 including five which are newly recognized here: Calypogeia peruviana (Fig. 1A), Ceratolejeunea coarina (Fig. 1B), C. ornithocephala (Fig. 1C),
Odontoschisma variabile (Fig. 1D), and Syzygiella manca. As a result, 74 Afro-American species (in 54 genera and 27 families) are recognized in this paper. Ten species occur also in Europe and five range eastwards to the Indian subcontinent. Plagiochila exigua occurs also in oceanic parts of the Holarctic but lacks in tropical Asia.

Most of the new records resulted from taxonomic revisionary work; a few were based on molecular work or were floristic discoveries, e.g., Cephalojonesia jonesia was found in Mexico new to tropical America (Burghardt et al. 2006) and Colura cylindrica, Kymatocalyx dominicensis, Lejeunea trinitensis, Mnioloma caespitosum, Plagiochila puntata and Symbiezidium barbiflorum were collected new to Africa by T. Pócs (e.g., Pócs 1990, 2005, 2010; Sass-Gyarmati \& Pócs 2002). An important addition is the genus Plagiochila, which lacked in our 1983 review and is now represented by five Afro-American species. Intercontinental species were long unknown in this large genus but were recently detected based on integrated morphological, chemical and molecular work (Groth et al. 2003).

Several species pairs listed by Gradstein et al. (1983) have proven to be conspecific as a result of taxonomic investigation, including Brachiolejeunea tristis (= B. chinantlana), Calypogeia peruviana (= C. afrocaerulea), Colura ornithocephala (=C. kilimanjarica), Frullania riojaneirensis $(=$ F. africana), Odontolejeunea lunulata $(=$ O. tortuosa), Pallavicinia spinosa (= P. erythropus) and Syzygiella manca (=S. geminifolia). In the case of Arachniopsis dissotricha and A. diplopoda the proposed sister status was confirmed by morphology (Engel \& Smith Merrill 2004, as Amazoopsis dissotricha and A. diplopoda), in the case of Leptoscyphus amphibolius and L. infuscatus by molecular evidence (Devos \& Vanderpoorten 2009). The latter authors showed that the lineage leading to L. amphibolius and L. infuscatus originated at the beginning of the Pliocene, about 5 million years ago. Sister status of Plagiochila columbica - P. integerrima and Porella capensis - P. swartziana, however, was refuted based on molecular analysis (Heinrichs et al. 2005b; Hentschel et al. 2007). The remaining species pairs listed by Gradstein 
Table 1. Afro-American liverwort species. Species added since 1983 are marked with an asterisk, those newly recognized in this paper are in bold face. Numbers in brackets refer to Notes on Afro-American species; names in brackets refer to names accepted by Gradstein et al. (1983). Elevational range: 1 = lowland; 2 = montane; 3 = alpine. Sexuality: $\mathrm{M}=$ monoicous; $\mathrm{D}=$ dioicous. Propagules: $+=$ present. Spore viabilility (van Zanten \& Gradstein 1988): $-=$ spores viable less than 1 day; $\mathrm{x}=$ viable 2-4 weeks; $\mathrm{xx}$ : viable more than 1 month.

\begin{tabular}{|c|c|c|c|c|c|c|}
\hline & $\begin{array}{l}\text { Elevational } \\
\text { range }\end{array}$ & Sexuality & $\begin{array}{l}\text { Propa- } \\
\text { gules }\end{array}$ & $\begin{array}{c}\text { Spore } \\
\text { viability } \\
(\mathrm{n}=13)\end{array}$ & $\begin{array}{c}\text { DNA } \\
\text { tested } \\
(\mathrm{n}=13)\end{array}$ & Notes \\
\hline${ }^{*}$ Acanthocoleus aberrans (1) & $1-2$ & $\mathrm{M}$ & & & & \\
\hline Acrolejeunea emergens & 1 & $\mathrm{D}, \mathrm{M}$ & + & & & also Sri Lanka and S India \\
\hline Adelanthus lindenbergianus & $2-3$ & $\mathrm{D}$ & + & & & also W Europe \\
\hline Aneura latissima (2) & $1-2$ & $\mathrm{D}$ & & & & \\
\hline $\begin{array}{l}\text { Apomarsupella africana } \\
\text { (= Marsupella africana) }\end{array}$ & 3 & $\mathrm{D}$ & & & & \\
\hline${ }^{*}$ Brachiolejeunea phyllorhiza (3) & 2 & $\mathrm{M}$ & & $\mathrm{x}$ & & \\
\hline${ }^{*}$ Calypogeia peruviana (4) & $2-3$ & $\mathrm{M}$ & + & & & \\
\hline${ }^{*}$ Caudalejeunea lehmanniana (5) & 1 & $\mathrm{D}, \mathrm{M}$ & + & & & \\
\hline${ }^{*}$ Cephalojonesia incuba (6) & 2 & $\mathrm{M}$ & & & & \\
\hline${ }^{*}$ Ceratolejeunea coarina (7) & $1(-2)$ & $\mathrm{M}$ & & & & \\
\hline${ }^{*}$ Ceratolejeunea cornuta $(8)$ & $1-2$ & $\mathrm{D}, \mathrm{M}$ & & & & \\
\hline $\begin{array}{l}\text { Cheilolejeunea unciloba } \\
\text { (= Leucolejeunea unciloba) }\end{array}$ & 1 & $\mathrm{M}$ & & $\mathrm{x}$ & & \\
\hline $\begin{array}{l}\text { Chiloscyphus martianus } \\
(=\text { Lophocolea martiana) }\end{array}$ & $1-2$ & M & & $\mathrm{x}$ & & \\
\hline${ }^{*}$ Cololejeunea papilliloba $(9)$ & 2 & M & + & & & \\
\hline${ }^{*}$ Colura calyptrifolia & 2 & M & + & & & $\begin{array}{l}\text { also W Europe, Sri Lanka and } \\
\text { Nepal }\end{array}$ \\
\hline${ }^{*}$ Colura cylindrica $(10)$ & $1(-2)$ & $\mathrm{M}$ & + & & & \\
\hline "Colura ornithocephala (11) & 3 & $\mathrm{D}, \mathrm{M}$ & & & & \\
\hline Exormotheca pustulosa (12) & $1-2$ & $\mathrm{M}$ & & & & also S Europe \\
\hline${ }^{*}$ Frullania ecklonii (13) & 2 & $\mathrm{M}$ & & & & also Asia? \\
\hline${ }^{*}$ Frullanoides tristis $(14)$ & 2 & $\mathrm{M}$ & & & & also S India and Nepal \\
\hline $\begin{array}{l}\text { Gymnocoleopsis cylindriformis } \\
(=G . \text { multiflora })\end{array}$ & $2-3$ & $\mathrm{M}$ & + & $\mathrm{x}$ & & $\begin{array}{l}\text { also Prince Edwards Is. and } \\
\text { Kerguelen (Schuster 2002; } \\
\text { Váňa et al. 2013) }\end{array}$ \\
\hline *Haplolejeunea cucullata (15) & 1 & $\mathrm{M}$ & & & & \\
\hline${ }^{*}$ Herbertus juniperoideus (16) & 2 & $\mathrm{D}$ & & $\mathrm{xx}$ & + & \\
\hline Hyaloplepidozia bicuspidata & 1 & $\mathrm{D}, \mathrm{M}$ & & & & \\
\hline Isotachis aubertii & $2-3$ & $\mathrm{D}$ & & & & \\
\hline Kurzia capillaris & $2-3$ & $\mathrm{D}$ & & & & \\
\hline${ }^{*}$ Kymatocalyx dominicensis (17) & $1-2$ & $\mathrm{M}$ & & & & \\
\hline *Jensenia spinosa $(18)$ & $2-3$ & $\mathrm{D}$ & & $\mathrm{xx}$ & & \\
\hline Lejeunea aphanes $(=$ L. autoica $)$ & 1 & $\mathrm{M}$ & & & & \\
\hline${ }^{*}$ Lejeunea capensis (19) & $1-2$ & $\mathrm{M}$ & & & & \\
\hline $\begin{array}{l}\text { Lejeunea phyllobola } \\
(=\text { Rectolejeunea brittoniae) }\end{array}$ & 1 & $\mathrm{D}$ & + & & & \\
\hline${ }^{*}$ Lejeunea trinitensis $(20)$ & $1-2$ & $\mathrm{M}$ & & & & peri-Afroamerican; also E Asia \\
\hline Lepicolea ochroleuca & & $\mathrm{D}$ & & & & \\
\hline Lepidozia cupressina & 2 & $\mathrm{D}$ & & & & also W Europe \\
\hline Leptoscyphus cuneifolius (21) & 2 & $\mathrm{D}$ & + & & + & also W Europe \\
\hline Leptoscyphus expansus (22) & $1-2$ & $\mathrm{D}$ & & & & \\
\hline
\end{tabular}


Table 1. Continued.

\begin{tabular}{|c|c|c|c|c|c|c|}
\hline & $\begin{array}{l}\text { Elevational } \\
\text { range }\end{array}$ & Sexuality & $\begin{array}{l}\text { Propa- } \\
\text { gules }\end{array}$ & $\begin{array}{c}\text { Spore } \\
\text { viability } \\
(\mathrm{n}=13)\end{array}$ & $\begin{array}{c}\text { DNA } \\
\text { tested } \\
(\mathrm{n}=13)\end{array}$ & Notes \\
\hline $\begin{array}{l}\text { Lophonardia jamesonii } \\
\text { (= Andrewsianthus jamesonii) }\end{array}$ & $2-3$ & $\mathrm{D}$ & + & $\mathrm{xx}$ & & \\
\hline $\begin{array}{l}\text { Lophonardia laxifolia } \\
(=\text { Lophozia argentina })(23)\end{array}$ & $2-3$ & $\mathrm{D}$ & & & & \\
\hline${ }^{*}$ Marchesinia brachiata (24) & 2 & $\mathrm{D}, \mathrm{M}$ & & $\mathrm{x}$ & + & \\
\hline $\begin{array}{l}\text { Marsupidium limbatum } \\
(=\text { Tylimanthus limbatus })\end{array}$ & $1-2$ & $\mathrm{D}$ & & & & \\
\hline Mastigolejeunea auriculata (25) & $1(-2)$ & $\mathrm{D}, \mathrm{M}$ & & & + & \\
\hline${ }^{*}$ Metzgeria agnewiae (26) & $2-3$ & $\mathrm{D}$ & + & & & \\
\hline${ }^{*}$ Metzgeria attenuata $(27)$ & $2(-3)$ & $\mathrm{D}$ & + & & & \\
\hline${ }^{*}$ Microlejeunea globosa (28) & 2 & $\mathrm{D}$ & + & & & \\
\hline${ }^{*}$ Mnioloma caespitosum (29) & $1-2$ & $\mathrm{D}$ & & & & \\
\hline *Odontolejeunea lunulata (30) & $1-2$ & $\mathrm{D}, \mathrm{M}$ & + & & & \\
\hline "Odontoschisma variabile (31) & 2 & $\mathrm{D}$ & + & & & \\
\hline${ }^{*}$ Oxymitra incrassata $(32)$ & $1-2$ & M & + & & & also S Europe and SW Asia \\
\hline${ }^{*}$ Plagiochila boryana $(33)$ & $2(-3)$ & $\mathrm{D}$ & & & + & \\
\hline *Plagiochila corrugata (34) & $1-2$ & $\mathrm{D}$ & + & & + & \\
\hline${ }^{*}$ Plagiochila exigua $(35)$ & 2 & $\mathrm{D}$ & + & & & $\begin{array}{l}\text { also oceanic regions of } \\
\text { Holarctic }\end{array}$ \\
\hline *Plagiochila punctata (36) & $1-3$ & $\mathrm{D}$ & + & & + & also W Europe \\
\hline${ }^{*}$ Plagiochila stricta $(37)$ & 2 & $\mathrm{D}$ & + & & + & peri-Afroamerican \\
\hline *Porella swartziana (38) & $1-2$ & $\mathrm{D}$ & & & + & \\
\hline $\begin{array}{l}\text { Pseudomarsupidium decipiens } \\
\text { (= Adelanthus decipiens) }\end{array}$ & 2 & $\mathrm{D}$ & & & & also W Europe \\
\hline Radula flaccida & 1 & $\mathrm{D}$ & + & & & \\
\hline *Radula quadrata (39) & $1-2$ & $\mathrm{D}$ & + & & & \\
\hline Radula stenocalyx & 2 & $\mathrm{D}$ & + & & & \\
\hline${ }^{*}$ Radula voluta $(40)$ & $2-3$ & $\mathrm{D}$ & & $\mathrm{x}$ & & also W Europe \\
\hline${ }^{*}$ Riccardia amazonica (41) & $1-2$ & $\mathrm{D}, \mathrm{M}$ & & - & & \\
\hline${ }^{*}$ Riccia curtisii $(42)$ & $1-2$ & $\mathrm{D}$ & & & & also SW Asia and India \\
\hline${ }^{*}$ Riccia membranacea $(43)$ & $1-2$ & $\mathrm{M}$ & & & & \\
\hline Schiffneriolejeunea polycarpa & $1-2$ & $\mathrm{D}, \mathrm{M}$ & & & & $\begin{array}{l}\text { also Sri Lanka, S India and } \\
\text { Thailand }\end{array}$ \\
\hline Schistochila alata & $1-2$ & $\mathrm{D}$ & & & & \\
\hline Sphaerocarpos stipitatus & 1 & $\mathrm{D}$ & & & & \\
\hline Stephaniella paraphyllina & 3 & $\mathrm{D}$ & & & & \\
\hline${ }^{*}$ Symbiezidium barbiflorum (44) & $1-2$ & $\mathrm{M}$ & & & & peri-Afroamerican \\
\hline Symphyogyna brasiliensis & 2 & $\mathrm{D}$ & & $\mathrm{xx}$ & & \\
\hline${ }^{*}$ Symphyogyna podophylla (45) & $1-2$ & $\mathrm{D}$ & & & + & \\
\hline Syzygiella concreta & 2 & $\mathrm{D}$ & & & + & \\
\hline${ }^{*}$ Syzygiella manca (46) & 2 & $\mathrm{D}$ & & & + & \\
\hline $\begin{array}{l}\text { Telaranea diacantha } \\
\text { (incl. T. coactilis) }\end{array}$ & $1-2$ & $\mathrm{D}, \mathrm{M}$ & + & & & \\
\hline Telaranea nematodes & 2 & $\mathrm{M}$ & & $\mathrm{x}$ & & \\
\hline${ }^{*}$ Tylimanthus laxus (47) & $2-3$ & $\mathrm{D}$ & + & & + & \\
\hline
\end{tabular}


et al. (1983) have not yet been verified and should be studied.

Lejeuneaceae are the best represented group among the Afro-American species, with almost one third of them belonging to this family (Table 2). Characteristic of Lejeuneaceae are multicellular green spores with endosporous protonemata, which were traditionally believed to be unsuited for LDD (e.g., Fulford 1951). Van Zanten and Gradstein (1988), however, found no difference in the viability of green spores and non-green spores of tropical liverworts. The large number of taxa with green spores among Afro-American liverwort species indicates that dispersibility of spores is not necessarily reduced by germination of protonema inside the spores before being released from the capsule.

The number of species shown to possess AfroAmerican ranges has almost doubled in the last thirty years. They constitute about $5 \%$ of the flora of tropical America, estimated at ca 1400 species (Gradstein et al. 2001, with updates), and about $8 \%$ of the flora of tropical Africa, estimated at ca 900 liverwort species (Wigginton 2009, with updates). When pantropical and wide-temperate species are also taken into account (Table 2 and below), the number of liverwort species shared by the two continents rises to 144 , or about $10 \%$ of the neotropical flora and $16 \%$ of the flora of tropical Africa.

2. FAMILIES AND GENERA. One liverwort family, Oxymitraceae, containing 2 species in the genus Oxymitra, is restricted to the mediterranean-subtropical regions of America and Africa + S Europe (Bischler 1998). At the generic level, Gradstein et al. (1983) listed eight taxa with ranges largely restricted to tropical Africa and America: Arachniopsis, Bryopteris, Haplolejeunea, Leptoscyphus, Marchesinia, Odontolejeunea, Stephaniella and Symbiezidium. The genera Arachniopsis (= Telaranea) and Leptoscyphus have since been shown to possess wider, pantropical distributions (Engel \& Smith Merrill 2004; Vanderpoorten et al. 2010). On the other hand, seven genera have newly been added to the list of Afro-American taxa: Amazoopsis (1 Am sp., 2 Afr. spp.), Aureolejeunea
(5 Am. spp., 1 sp. on St. Helena), Brachiolejeunea (Spruce) Schiffn. (4 Am. spp., 1 Afro-Am. sp.), Cephalojonesia Grolle \& Vanden Berghen (1 AfroAm. sp.), Frullanoides Raddi (6 Am. spp., 1 AfroAm. sp.), Oxymitra (1 Afro-Am. sp., 1 Afr. sp.) and Xylolejeunea (2 Am. spp., 2 Afr. sp.). As a result, the total number of Afro-American liverwort genera has risen to thirteen. Nevertheless, their number is limited and includes less than ten percent of all the genera known from tropical America ( ca 170) or from tropical Africa ( $c a$ 140). Most of the Afro-American genera are Lejeuneaceae, with three-quarters being members of this family. Further Afro-American hepatics may exist at the subgeneric and sectional level but these have not been taken into account in this study.

3. CAUSES OF THE AFro-AmERICAN RANGES. Spore germination experiments and molecularphylogenetic studies carried out on 23 AfroAmerican species (Table 1) have supported the dispersal hypothesis (LDD) rather than vicariance as explanation of the intercontinental ranges, also for most of the transoceanic genera. Nevertheless, the number of taxa studied by means of molecular analysis and by spore viability tests is still limited and much more work of this kind should be carried out. As shown in Table 1, bisexual spores and asexual propagules are relatively common among the intercontinentally distributed taxa, with almost half of the Afro-American species having bisexual spores (viz. being monoicous), while asexual propagules occur in about one third of the species. Bisexual spores rare only among alpine species. Interestingly, asexual propagules are more common among dioicous Afro-American species (40\%) than among monoicous species (30\%). This agrees with the notion that asexual reproduction may increase the chances of successful LDD in species with unisexual populations (Heinrichs et al. 2006).

It is generally assumed that LDD of hepatics and of spore plants in general should take place via wind or, in the case of amphitropical taxa (see below) and species with very large spores, via migratory birds. Direct evidence for LDD from scrutiny of air samples or captured birds is lacking, however. Introduction by man as a cause of the 
Table 2. Number of Afro-American, Afro-Asiatic and pantropical species in families of liverworts. Family circumscriptions follow Crandall-Stotler et al. (2009). Number of species per family follows Gradstein et al. (2001) and Frey (2009) with updates. For lists of Afro-Asiatic and pantropical species see Appendices 1 and 2.

\begin{tabular}{|c|c|c|c|c|}
\hline Family & $\begin{array}{c}\text { Afro- } \\
\text { American } \\
\text { species }\end{array}$ & $\begin{array}{l}\text { Afro-Asiatic } \\
\text { species }\end{array}$ & $\begin{array}{l}\text { Pantropical } \\
\text { species* }\end{array}$ & $\begin{array}{l}\text { Total number of species } \\
\text { (total number of species per family) }\end{array}$ \\
\hline Lejeuneaceae & 23 & 35 & 21 & $78($ ca 1250) \\
\hline Scapaniaceae & 2 & 3 & 7 & $12($ ca 350) \\
\hline Ricciaceae & 2 & & 9 & $11(\mathrm{ca} 150)$ \\
\hline Lepidoziaceae & 5 & 4 & 2 & $11(\mathrm{ca} 500)$ \\
\hline Radulaceae & 4 & 4 & & $8($ ca 200) \\
\hline Frullaniaceae & 1 & 3 & 4 & $8(c a 300)$ \\
\hline Lophocoleaceae & 4 & 2 & 1 & $7(c a 200)$ \\
\hline Jamesoniellaceae & 2 & 2 & 2 & $6(c a 50)$ \\
\hline Aytoniaceae & & 3 & 2 & $5(c a 50)$ \\
\hline Pallaviciniaceae & 3 & 1 & 1 & $5(c a 50)$ \\
\hline Cephaloziellaceae & 3 & 2 & & $5(c a 80)$ \\
\hline Metzgeriaceae & 2 & & 3 & $5(c a 100)$ \\
\hline Plagiochilaceae & 5 & & & $5(c a 400)$ \\
\hline Aneuraceae & 2 & & 2 & $4(c a 200)$ \\
\hline Marchantiaceae & & & 3 & $3(38)$ \\
\hline Calypogeiaceae & 2 & 1 & & $3(c a 50)$ \\
\hline Cyathodiaceae & & 1 & 2 & $3(12)$ \\
\hline Haplomitriaceae & & & 2 & $2(9)$ \\
\hline Adelanthaceae & 2 & & & $2(c a 20)$ \\
\hline Herbertaceae & 1 & 1 & & $2(c a 30)$ \\
\hline Acrobolbaceae & 2 & & & $2(c a 40)$ \\
\hline Porellaceae & 1 & 1 & & $2(c a 60)$ \\
\hline Gymnomitriaceae & 1 & & 1 & $2(c a 70)$ \\
\hline Cephaloziaceae & 1 & & 1 & $2(c a 75)$ \\
\hline Antheliaceae & & & 1 & $1(1)$ \\
\hline Lunulariaceae & & & 1 & $1(1)$ \\
\hline Wiesnerellaceae & & 1 & & $1(1)$ \\
\hline Oxymitraceae & 1 & & & $1(2)$ \\
\hline Dumortieraceae & & & 1 & $1(2)$ \\
\hline Targioniaceae & & & 1 & $1(3)$ \\
\hline Calyculariaceae & & & 1 & $1(4)$ \\
\hline Mastigophoraceae & & 1 & & $1(4)$ \\
\hline Pleuroziaceae & & 1 & & $1(9)$ \\
\hline Exormothecaceae & 1 & & & $1(10)$ \\
\hline Lepicoleaceae & 1 & & & $1(10)$ \\
\hline Sphaerocarpaceae & 1 & & & $1(10)$ \\
\hline Geocalycaceae & & 1 & & $1(18)$ \\
\hline Arnelliaceae & 1 & & & $1($ ca 20) \\
\hline Pseudolepicoleaceae & & & 1 & $1(\mathrm{ca} 25)$ \\
\hline Balantiopsidaceae & 1 & & & $1(\mathrm{ca} 40)$ \\
\hline Fossombroniaceae & & 1 & & $1(c a 80)$ \\
\hline Schistochilaceae & 1 & & & $1(c a 90)$ \\
\hline Solenostomataceae & & & 1 & $1(c a 100)$ \\
\hline (Jungermanniaceae s.str.) & & & & $0(c a 40)$ \\
\hline (Trichocoleaceae) & & & & $0(c a 35)$ \\
\hline (Cleveaceae) & & & & $0($ ca 20$)$ \\
\hline (Lepidolaenaceae) & & & & $0(18)$ \\
\hline (Riellaceae) & & & & $0(15)$ \\
\hline (Treubiaceae) & & & & $0(11)$ \\
\hline (rest families of $<10 \mathrm{spp}$.) & & & & $0(c a 50)$ \\
\hline TOTAL & 75 & 68 & 70 & $212(c a 5000)$ \\
\hline
\end{tabular}

${ }^{*}$ Including species extending to temperate regions. 
intercontinental disjunctions of tropical hepatics is rarely suggested and seems to have played no role of importance. Gradstein et al. (1983) mentioned a single case, viz. the record of Exormotheca pustulosa in the botanical garden of Mexico City, which was the only collection of this Mediterranean-African species from the New World. Recently, two further Mexican records of Exormotheca pustulosa have become available, both from natural environments (Bischler et al. 2005). The possibility that the species migrated to Mexico via natural means and was not a human introduction cannot, therefore, be ruled out. Gradstein and Váňa (1987) suggested that Jungermannia sphaerocarpa, Lophozia incisa and Diplophyllum obtusatum might have been introduced in tropical America because all neotropical records are from man-made habitats, viz. road banks (Gradstein \& Váňa 1987). The subcosmopolitan Lunularia cruciata might also have been introduced in the tropics because most tropical records are from greenhouses or other artificial habitats, few from natural habitats (Bischler et al. 2005). The occurrence of widespread bryophyte species on remote oceanic islands such as Hawaii or Tahiti, finally, is usually explained by LDD but the possibility that some of these were actually introduced cannot be ruled out.

\section{PERI-AFroAmERICAN AND AMPHITROPICAL} RANGES. Several liverwort taxa have marked periAfroamerican ranges, being known from tropical America and the East African islands but not from the African mainland (Fig. 1F). These ranges are usually explained by the extinction of the species on the mainland of Africa during the Pleistocene, due to the drying-out of the African continent during the pleistocenic glaciations (Stearn 1971; Moore 1973). Well-known examples from hepatics are the genera Symbiezidium and Bryopteris (Gradstein et al. 1983), both of which are very common in the Neotropics and very rare in Africa. Symbiezidium has three species in the Neotropics and two on the East African islands: S. madagascariense Steph. on Madagascar and the Seychelles and S. barbiflorum in NE Madagascar (Sass-Gyarmati \& Pócs 2002). The latter species also occurs in tropical America where it is very common (Fig. 1F). Bryopteris has two common species in the Neotropics and one, B. gaudichaudii, very rare in Madagascar (Stotler \& Crandall-Stotler 1999; Hartmann et al. 2006).

The recent discovery of two new members of the neotropical genus Xylolejeunea, X. grolleana and $X$. muricella, on the East African islands (Pócs 1999; He \& Grolle 2001) adds a striking further example of a peri-Afroamerican liverwort genus. Further new examples of peri-Afroamerican hepatics are Plagiochila stricta and Lejeunea trinitensis; both were discovered on the East African islands by T. Pócs and were new to Africa. Examples of peri-Afroamerican mosses are Adelothecium bogotense, Calymperes venezuelanus, Phyllodrepanium falcifolium, Phyllogonium fulgens and $P$. viride (Gradstein et al. 1983; Pócs 1999). Interestingly, many peri-Afroamerican taxa grow in Africa in the understory of dense rainforest (e.g., He \& Grolle 2001; exception: Lejeunea trinitensis). The preference of these species for wet, shaded habitats coincides with their presumed extinction during the climatically dry periods of the Pleistocene.

Two Afro-American liverwort species, Microlejeunea globosa and Oxymitra incrassata, have marked amphitropical ranges, occurring in subtropical regions at the northern and southern edges of the Tropics and being absent or very rare in the tropical belt (Fig. 1E). The amphitropical ranges of plant species are usually explained by dispersal via migratory birds with migration routes across the tropical belt. Carlquist (1983) found that more than $80 \%$ of angiosperm species with amphitropical ranges (ca. $100 \mathrm{spp}$.) had fruits that were hairy, sticky or fleshy, and were very well suited for bird dispersal (see also Cruden 1966). Among hepatics, amphitropical ranges are found in the two abovementioned species and in Chonecolea doellingeri, Cronisia fimbriata and Riccia lamellosa (Gradstein et al. 2001; Bischler et al. 2005). All of them grow in arid habitats and most of them have large spores which might be more suited for bird dispersal than for dispersal via wind. The viability of the spores of these amphitropical hepatics has not been tested, however, and should be studied.

5. Afro-American, Afro-Asiatic AND PANTROPICAL RANGES (Table 2 and APPENDICES 

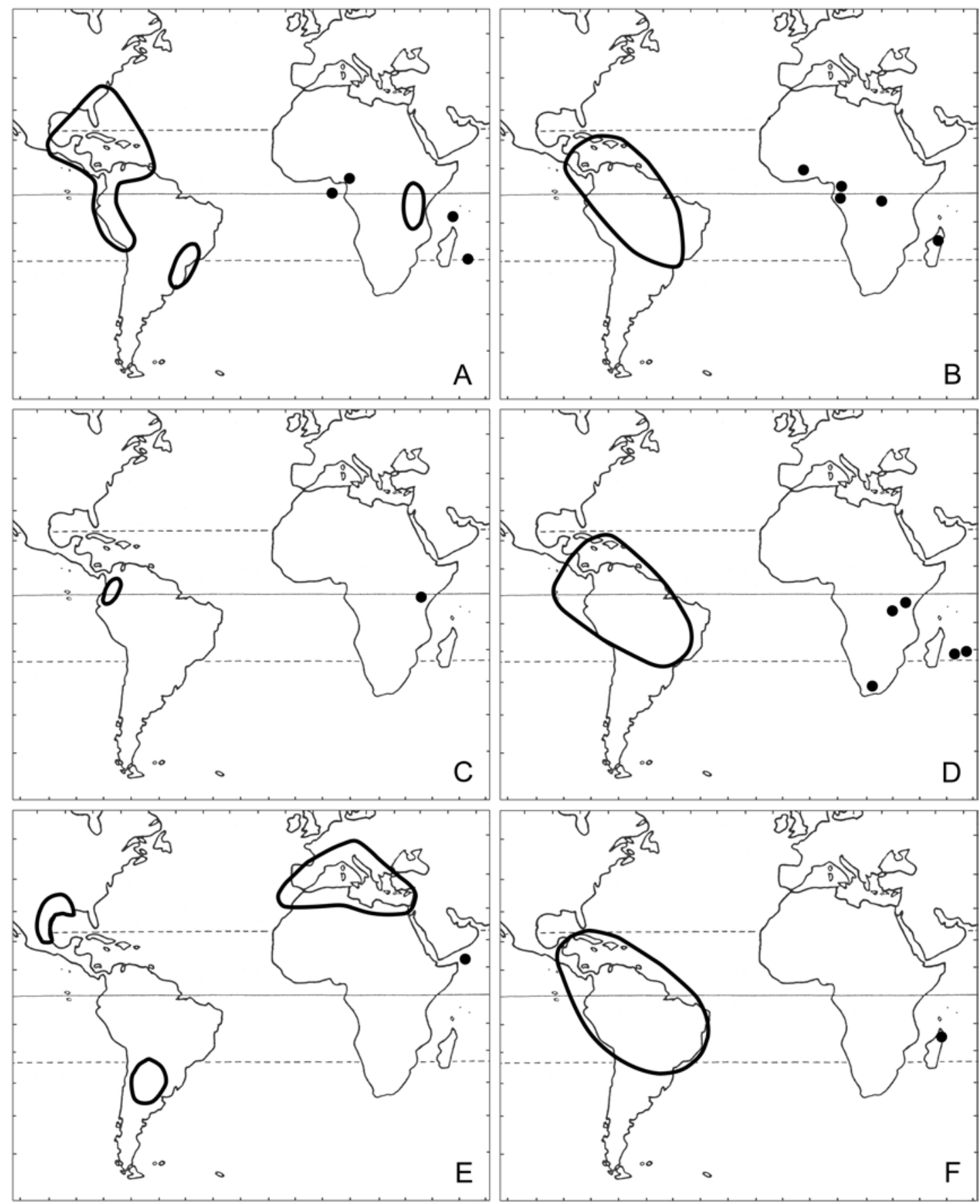

Fig. 1. Distribution of Afro-American liverwort species. A - Calypogeia peruviana Nees \& Mont., B - Ceratolejeunea coarina (Gottsche) Steph., C - Colura ornithocephala Herzog, D - Odontoschisma variabile (Lindenb. \& Gottsche) Trevis., E - Oxymitra incrassata Lindenb., F - Symbiezidium barbiflorum (Lindenb. \& Gottsche) Trevis. 
1 \& 2). Herzog (1926), in his classical account on the geography of bryophytes, found that the floras of Africa and tropical America had more bryophyte genera in common than those of tropical Africa and Asia. A greater bryological similarity between the floras of tropical Africa and tropical America was also reported by Gradstein et al. (1983), who found more Afro-American liverwort species (41) than Afro-Asiatic ones (35; based on Pócs 1976). ${ }^{1}$

An updated comparison of the numbers of Afro-American, Afro-Asiatic and pantropical species is shown in Table 2. The data confirm that America and Africa have slightly more species in common (74) than tropical Africa and Asia (68). The number of pantropical species (70) is almost identical to that of Afro-Asiatic species. In addition, a few species occur in tropical America and tropical Asia but are unknown from tropical Africa (e.g. Ceratolejeunea grandiloba; Gradstein 2013). Their absence in Africa is probably an artefact and further collecting may show their presence there.

Interestingly, more than $90 \%$ of the AfroAmerican species occur in East Africa and only about $40 \%$ in West Africa. Similar percentages are observed for the Afro-Asiatic species. The higher frequency of Afro-American species in East Africa may be explained by the fact that most of Africa's high mountains are in the eastern part of the continent; the occurrence of land over $1000 \mathrm{~m}$ is rather limited in West Africa (Harrington \& Jones 2004).

Intercontinentally distributed species occur in many liverwort families and are usually relatively few per family. Jamesoniellaceae have the highest percentage of intercontinental species $(12 \%)$, lowest percentages are found in Fossombroniaceae, Plagiochilaceae, Schistochilaceae and

\footnotetext{
1 The greater number of liverwort species shared between tropical Africa and tropical America than between Africa and Asia does not conflict with the phytogeographical subdivision into 'Neotropics' and Paleotropics' which is based on endemism, not on shared taxa. Although endemism in the Tropics is usually considered to be highest in tropical America (e.g., Schuster 1990), an assessment of hepatic endemism in tropical America, Africa and Asia based on current knowledge is lacking and should be undertaken.
}

Solenostomataceae (ca. 1\%). Lejeuneaceae contain the largest number of intercontinental species (78) but these represent a low $7 \%$ of the total number of species in the family. ${ }^{2}$

The number of genera among Afro-American and Afro-Asiatic taxa is about the same (13 resp. 12) and is low. Indeed, most of the genera of tropical hepatics are widespread throughout the tropics and have pantropical distributions (number not counted); many of them may also extend into temperate regions.

\section{NOTES ON AFRO-AMERICAN LIVERWORT SPECIES}

The ranges of the Afro-American species added since 1983 are briefly discussed here. In addition, a few Afro-American ranges treated by Gradstein et al. (1983) for which important new evidence has come available, are described. For discussions of the remaining Afro-American species see Gradstein et al. (1983).

1. Acanthocoleus aberrans (Lindenb. \& Gottsche) Kruijt

Acanthocoleus aberrans is a widespread Afro-American (+ Macaronesian) species with many synonyms (Kruijt 1988; Gradstein 1994). In the Neotropics the species occurs scattered in C America, Caribbean, N Andes and SE Brazil, in rather dry, semi-deciduous woodlands and the outer canopy of rainforests, up to $2600 \mathrm{~m}$ elevation. In tropical Africa the species grows in similar habitats up to about $2000 \mathrm{~m}$. Jones (in Wigginton 2004), however, did not accept the occurrence of $A$. aberrans in Africa and treated most of the

\footnotetext{
2 In Table 2 the total estimated number of the liverwort species is $c a$ 5000. This number agrees with Gradstein et al. (2001), Gradstein and Costa (2003), Crandall-Stotler et al. (2009) and others, and is lower than $c a 7500$ species proposed by von Konrat et al. (2010). This discrepancy is explained by the average synonymy rates in liverwort monographs, which was calculated at a low $70 \%$ by von Konrat et al. (2010). Their synonymy rate would have been higher when a larger number of world monographs would have been included in the calculation (e.g., Bischler 1984, 1989, 1993; van Slageren 1985; Kruijt 1988; Gradstein 1975, 1994; etc.) and precursors such as Engel and Smith Merrill (2004) omitted.
} 
African material as Dicranolejeunea madagascariensis Steph.

Acanthocoleus R. M. Schust. is closely related to Dicranolejeunea (Spruce) Schiffn. and is sometimes considered a subgenus of the latter (Kruijt 1985, Jones in Wigginton 2004). The two groups are separated by predominance of Frullania- or Lejeunea-type branching, epidermal cells bulging outwards or not, and the toothed vs entire inner female bracteole (Kruijt 1988; Gradstein 1994). Because the morphological differences between Acanthocoleus and Dicranolejeunea are minor ones, treating Acanthocoleus as a subgenus of Dicranolejeunea seems reasonable. This should be checked by molecular analysis.

\section{Aneura latissima Spruce}

= A. pseudopinguis (Herzog) Pócs, syn. nov.

Aneura latissima described from Amazonia and A. pseudopinguis described from S Brazil are closely related (Gradstein et al. 1983, 2003). The two species differ only in thallus thickness, being to 3 cells thick in A. latissima (data based on Spruce 1885) and 5-8 cells in A. pseudopinguis. According to R. Rico (pers. com.), however, the thallus of $A$. latissima is $6-9$ cells thick, not 3 cells. The erroneous measurement was due to the fact that the thallus cells in the old type material were collapsed. As shown by Rico (2011), old herbarium material of Riccardia must be rehydrated with sodium hypochlorite for study of the thallus morphology.

Aneura latissima grows on moist soil, rock and rotten wood in lowland and montane rainforests to over $2000 \mathrm{~m}$ elevation, and is known from many African localities (Meenks \& Pócs 1985, as $A$. pseudopinguis) and from a few localities in Brazil (states of Amazonas, Sao Paulo and Santa Catarina). The species is probably more widespread in tropical America where it has probably been confused with $A$. pinguis. The latter species differs by having a thicker thallus, shorter antheridial branches and larger spores (Meenks \& Pócs 1985). The neotropical records of $A$. pinguis should be checked for possible further localities of $A$. latissima.

\section{Brachiolejeunea phyllorhiza (Nees) Kruijt \& Gradst.}

Brachiolejeunea phyllorhiza was originally described as a member of Dicranolejeunea but was transferred to Brachiolejeunea (sect. Phyllorhizae Gradst.) by its broad ventral merophyte, homogeneous oil bodies, dorsal cortical cells larger than ventral ones and winged female bracts with large lobules (Kruijt \& Gradstein 1986; Gradstein 1994). The species was long considered endemic to tropical America but Kruijt and Gradstein (1986) recorded it from Africa where it was known under several names. The occurrence of $B$. phyllorhiza in Africa concurs with its durable spores, which retain their capacity for germination up to 40 days after drying (van Zanten \& Gradstein 1988). The species grows on bark and rock in rather dry, open forests and plantations or on roadside trees, at elevations between $400-2500 \mathrm{~m}$, and is rather widespread in tropical America, although being nowhere common. In Africa the species is rare and recorded from Kenya, Zimbabwe and S Africa.

\section{Calypogeia peruviana Nees \& Mont. Fig. 1A}

$=$ C. afrocaerulea E. W. Jones, syn. nov.

Calypogeia peruviana is common in tropical America and morphologically highly variable. Probably the most striking feature of the species are the oil bodies, which vary in colour from bright blue to purplish to sepia (Schuster 1969, 1995; Gradstein et al. 1977, 2001). Blue oil bodies also occur in $C$. afrocaerulea from Africa, which is generally considered very close to $C$. peruviana. Jones (1976) separated C. afrocaerulea from C.peruviana by the less strongly arched antical leaf margin, the rather large plant size and the common occurrence of a blunt tooth on the underleaf margins. All these characters, however, overlap with $C$. peruviana and the two should therefore be considered conspecific. Calypogeia peruviana is widespread in the mountains of tropical America, ranging northwards to southeastern USA and southwards to southern Brazil, from 250 to $3800 \mathrm{~m}$ elevation. The African range of C. peruviana is more scattered and includes São Tomé, Mt. 
Cameroun, the east African mountains, Seychelles and Réunion (Wigginton 2009).

\section{Caudalejeunea lehmanniana (Gottsche)}

A. Evans

Caudalejeunea lehmanniana is widespread in tropical America where it occurs on bark and living leaves in mesic evergreen forests and scrub at rather low elevations, to $1000 \mathrm{~m}$ (Gradstein 1994). The species also occurs in W Africa where it was described as $C$. tricarinata E. W. Jones. The latter species was reduced to synonymy under $C$. lehmanniana by Schuster (1980). Jones (in Wigginton 2004), however, doubted this synonymy, pointing out that the African plants have broader leaves and bracts and a more conspicuously winged perianth. Possibly, the African populations represent a separate subspecies. The relationships of the neotropical and African populations of C. lehmanniana need further study, preferably by molecular analysis.

\section{Cephalojonesia incuba Grolle \& Vanden Berghen}

Cephalojonesia Grolle \& Vanden Berghen, with the single species $C$. incuba, was long considered endemic to Africa but was recently discovered in Mexico (Burghardt et al. 2006). Based on slight differences in the gynoecium, the Mexican plant was described as a separate subspecies, C. incuba subsp. mexicana Burghardt et al. Cephalojonesia incuba subsp. incuba occurs in Central Africa (Nigeria, Zaire, D.R. Congo, Kenya), where it is a rare and known from no more than half a dozen localities. The subsp. mexicana is thus far known from only one location in a moist pine-oak forest in W Michoacán, Mexico. The species grows primarily on conifer trunks, at $c a$ 800-1200 m elevation in Africa and at $2400 \mathrm{~m}$ in Mexico.

\section{Ceratolejeunea coarina (Gottsche) Steph.}

Fig. 1B

= C. diversicornua Steph., syn. nov.

Ceratolejeunea coarina is one of the few typical epiphyllous species in the genus Ceratolejeunea and is widespread in tropical America, where has been described under several names, including C. plumula Spruce (Dauphin 2003). Vanden Berghen (1951) and Pócs (2011) noted a close relationship with the African $C$. diversicornua (= C. cornutissima Steph.) and critical comparison of $C$. coarina and $C$. diversicornua shows that they are identical. Ceratolejeunea coarina occurs in lowland and submontane rainforests up to $1200 \mathrm{~m}$ elevation and is rather common in tropical America but is rare in Africa, where it is known from Ghana, Cameroun, Gabon, E Zaire and Madagascar (Pócs 2011).

\section{Ceratolejeunea cornuta (Lindenb.) Steph.}

Ceratolejeunea cornuta is a common and widespread Afro-American species and grows on bark, rock and living leaves in moist forests and secondary, open habitats from sea level to over 2000 m (Dauphin 2003; Pócs 2011, Fig. 81). In Africa the species was known as $C$. calabariensis Steph., which is a synonym (Pócs 2011). Pócs also noted a close relationship between $C$. cornuta and the widespread palaeotropical $C$. belangeriana (Gottsche) Steph. (=C. oceanica Steph.), and suggested that the latter might be a subspecies of C. cornuta. The two are mainly separated by the absence of spherical lobules in $C$. belangeriana. A further study of the relationships of $C$. belangeriana and $C$. cornuta using molecular evidence should be carried out.

\section{Cololejeunea papilliloba Steph.}

This rare SE Brazilian species has recently been collected on Bioko Island, Equatorial Guinea (Müller \& Pócs 2007). Cololejeunea papilliloba grows as an epiphyll in montane rainforests at about 1000-1300 m elevation. Little information is available on the species.

\section{Colura cylindrica Herzog}

Colura cylindrica Herzog occurs scattered in tropical America (e.g. Cuba, Colombia, Ecuador, Guianas, Amazonia) where it grows as a sun epiphyte on twigs and living leaves in moist lowland forest to 600 m elevation (Gradstein \& Costa 2003; Léon-Yánez et al. 2006; Gradstein \& Ilkiu-Borges 
2009). In Africa the species is known from Nguru Mountains in Tanzania, where it was collected by T. Pócs from twigs in submontane rainforest, at 900-1060 m elevation (Pócs 1990).

\section{Colura ornithocephala Herzog 1952}

Fig. 1C

= Colura kilimanjarica Pócs \& Ast 1980, syn. nov.

Gradstein et al. (1983) considered the neotropical C. ornithocephala and the African C. kilimanjarica a closely related species pair, differing only in sexuality (C. ornithocephala dioicous, C. kilimanjarica autoicous) and in the frequent presence of a small, beak-like apicule at the tip of the sac in C. ornithocephala (Jovet-Ast 1980). In C. kilimajarica the apex of the sac is rounded to acute, without a beak-like apicule. However, these morphological data were based on only one single collection (the type) of each of the two species. While $C$. kilimanjarica is still only known from the type, several additional collections of C. ornithocephala have become available from S America collected by A. Schäfer-Verwimp and the author. The new specimens show that $C$. ornithocephala is autoicous (A. Schäfer-Verwimp. pers. com.), not dioicous, and that a beak-like projection on the sac is present only occasionally in this species. Most leaves in $C$. ornithocephala have in fact a rounded or acute apex, like in C. kilimanjarica. The new observations demonstrate that the morphological characters of the two species overlap and they are therefore treated here as conspecific. Colura ornithocephala occurs on bark of trees and shrubs near the forest line in the N Andes (Colombia, Ecuador), between 2900-3800 m. In Africa the species is known only from Mt. Kilimanjaro, from a similar habitat, where it was collected by T. Pócs.

\section{Exormotheca pustulosa Mitt.}

Gradstein et al. (1983) recorded the mediterranean-African Exormotheca pustulosa from a single American locality, the botanical garden of Mexico City, and suggested that the species might have been introduced in the New World by man.
However, Bischler et al. (2005) reported two further Mexican records, both from natural environments, at 2150-2300 m elevation. The possibility should therefore not be ruled out that E. pustulosa migrated from the Old World to Mexico via natural means and was not introduced. The species grows on sandy soil and soil-covered rock outcrops in areas with a dry mediterranean or subtropical climate, in temporarily moist habitats, from sea level to $2300 \mathrm{~m}$ depending on latitude.

\section{Frullania ecklonii (Spreng.) Spreng.}

Frullania ecklonii is widespread in tropical Africa and tropical America where it occurs throughout the montane belt, from 500 to $3500 \mathrm{~m}$ elevation. The species has sometimes been considered a synonym of $F$. obscura (Sw.) Dumort. [=F. arecae (Spreng.) Gottsche] but Demaret and Vanden Berghen (1948) and Yuzawa (1991) showed that the two are distinct. Yuzawa (1991) also mentioned its occurrence in tropical Asia but did not cite any specimens from Asia. Frullania ecklonii is therefore treated here as an AfroAmerican species. The Afro-American range of the species was already shown by Demaret and Vanden Berghen (1948) and was overlooked by Gradstein et al. (1983).

\section{Frullanoides tristis (Steph.) van Slageren}

Frullanoides tristis is widely distributed in tropical America and Africa, where it grows as an epiphyte, rarely on rock, in primary and secondary rainforests and along roadsides, between 500-2600 m (van Slageren 1985; Gradstein 1994). In addition, the species occurs in India and in Nepal where it had been described as Brachiolejeunea poeltii Grolle. Frullanoides tristis is paroicous and its spores may be suitable for long-distance dispersal across the Atlantic since good droughttolerance of spores was found in the sister species F. densifolia (van Zanten \& Gradstein 1988).

\section{Haplolejeunea cucullata (Steph.) Grolle}

Haplolejeunea cucullata is a rare Afro-American species from trunk bases in lowland rainforest. 
It is known from one locality in Cameroon (the type) and from several localities in SE Brazil, Amazonia and the Guianas (Grolle 1979b; SchäferVerwimp 1992; Gradstein \& Hekking 1989; IlkiuBorges 2000; Wigginton 2004). The records from Amazonia and the Guianas are doubtful, however, and in need of verification; as shown by Gradstein and Ilkiu-Borges (2009), the specimens from French Guiana belong to another taxon. A revision of the neotropical collections of $H$. cucullata is necessary and is being undertaken by Ilkiu-Borges and Gradstein (in prep.).

\section{Herbertus juniperoideus (Sw.) Grolle}

Herbertus juniperoideus (subsp. juniperoideus sensu Feldberg \& Heinrichs 2006), described by Swartz from Jamaica in 1788 , is widespread in tropical America where it occurs throughout the montane belt up to the forest line, from 500 to $3500 \mathrm{~m}$ (Feldberg \& Heinrichs 2006). In Africa the species is known from montane forest of Cameroon, Rwanda, Tanzania, Madagascar and the Seychelles, at elevations between 700-2150 m (Hodgetts 2008. Its occurrence in Africa had long been suggested and was recently confirmed based on morphological and molecular evidence (Feldberg et al. 2007; Hodgetts 2008). Although H.juniperoideus is dioicous, lacks means of asexual reproduction and produces sporophytes only infrequently, germination experiments indicate that its spores are highly drought resistant and remain viable after several months after drying (van Zanten \& Gradstein 1988, under H. subdentatus). It is therefore likely that the species attained its disjunct Afro-American range by LDD across the Atlantic.

\section{Kymatocalyx dominicensis (Spruce) Ván̆a}

Kymatocalyx dominicensis is a characteristic rheophyte from rocks in rivers, waterfalls etc., in lowland and lower montane rainforest areas to $2000 \mathrm{~m}$ elevation (Gradstein \& Ván̆a 1999). The species occurs scattered in tropical America and, in addition, has been recorded from Madagascar (Antongil Bay) and Uganda (O'Shea et al. 2003).

\section{Jensenia spinosa (Lindenb. \& Gottsche)} Grolle

The neotropical J. erythropus Gottsche and the African J. spinosa were long considered closely related (Grolle 1979a; Gradstein et al. 1983) and were shown to be conspecific by Schuette and Stotler (2005). Jensenia spinosa is a common terrestrial species of moist páramo and upper montane areas in tropical America and Africa, occurring at ca 2000-4000 m elevation. Although being dioicous and lacking asexual propagules, the species is frequently fertile and produces highly durable spores with a drought tolerance of up to at least two month (van Zanten \& Gradstein 1988, under J. erythropus), which should enhance its chances of successful dispersal across the Atlantic.

\section{Lejeunea capensis Gottsche}

Lejeunea capensis, a common African species, was recorded from SE Brazil by Giancotti and Vital (1989) and Schäfer-Verwimp (1992). More recently, the species has proved to be widespread in tropical America where it was described under many different names (Reiner-Drehwald \& SchäferVerwimp 2008). Lejeunea capensis grows on bark in rather open forests and plantations, up to $2150 \mathrm{~m}$ elevation, and is readily recognized by its eplicate perianth, rounded leaf apex, finely papillose cuticle and small, bifid underleaves.

\section{Lejeunea trinitensis Lindenb.}

Lejeunea trinitensis (= L. pililoba Spruce) is widespread in tropical America, where it grows on living leaves, bark, rotten logs or shaded rock in rather mesic evergreen woodlands, degraded rainforests and swamp forests, from sea level to $800 \mathrm{~m}^{3}$. The species is particularly common on the Caribbean islands and in SE Brazil and N Argentina, less frequent elsewhere. Recently, the species been discovered by T. Pócs on the Comores, where it occurs in similar habitats to those in tropical America (Pócs 1995, 2010 as

\footnotetext{
3 Stylolejeunea asitica Tixier \& Ast from Vietnam is conspecific with $L$. trinitensis according to Reiner-Drehwald \& Grolle (Nova Hedwigia 95: 476. 2012).
} 
L. pililoba). Lejeunea trinitensis is an example of a peri-Afroamerican species (see above).

\section{Leptoscyphus cuneifolius (Hook.) Mitt.}

Leptoscyphus cuneifolius is widespread in the New World, from SE U.S.A. to S Chile, and, additionally, occurs along the Atlantic coast of Great Britain, on Madeira and the Azores, and on Tristan da Cunha, but is unknown from mainland Africa (Gradstein et al. (1983). The species occurs at high elevations (2000-4500 m) on the mainland of tropical America, but at lower montane elevations on islands and at higher latitudes. Devos and Vanderpoorten (2009) sequenced material of L. cuneifolius and found considerable genetic divergence between British and neotropical populations, reflecting their long-term separation and indicating the occurrence of cryptic speciation in the species.

\section{Leptoscyphus expansus (Lehm.) Grolle}

In his monograph of the genus Leptoscyphus, Grolle (1962) placed several southern S American species in the synonymy of Leptoscyphus expansus, a species originally described from South Africa. As a consequence, L. expansus obtained an Afro-American range and this has been accepted by most authors (e.g., Fulford 1976, Engel 1978, Gradstein et al. 1983, Ván̆a \& Engel 2013). Hässel de Menendez (2001), however, excluded the S American taxa from the synonymy and treated L. expansus as a purely African species; the latter opinion was accepted by Vanderpoorten et al. (2010). The opinion of Hässel de Menendez (2001) is inconvincing, however, since she failed to examine specimens of $L$. expansus from Africa. In contrast, a broad range of specimens from both Africa and America was studied by Grolle (1962). In the present paper, therefore, L. expansus is defined in the broad sense following Grolle (1962). Since the latter publication, most work on $L$. expansus has focused on the S American populations and little attention has been paid to the $\mathrm{S}$ African populations. I suggest that a detailed molecular study using specimens from both continents is carried out to test the range of the species.
23. Lophonardia laxifolia (Mont.) L. Söderstr. \& Váňa

Lophonardia laxifolia (= Lophozia laxifolia (Mont.) Steph.) is widespread in the Andes and the high mountains of Central America where it has been described under many different names (Engel \& Váňa 2013; Söderström et al. 2013). One of its synonyms is Lophozia argentina (Steph.) R.M. Schust., a poorly known taxon recorded from northern Argentina and again from the Drakenberg, South Africa, where it was described as Lophozia montaguensis S. Arn. (Gradstein et al. 1983). By the inclusion of L. argentina in L. laxifolia, the latter species becomes Afro-American in distribution, ranging from Mexico to Tierra del Fuego and again in South Africa. Lophozia laxifolia grows on moist soil and rock in rather open locations at high montane and alpine elevations, between $2000-4500 \mathrm{~m}$ in the Neotropics and at lower elevation in Tierra del Fuego. In South Africa it was found at about $2600 \mathrm{~m}$. The range of L. laxifolia resembles that of Stephaniella paraphyllina, which also occurs from Mexico to N Chile and again in the Drakensberg, South Africa (see map in Gradstein et al. 1983). Stephaniella paraphyllina reaches less far south, however, and is not known from Patagonia.

\section{Marchesinia brachiata (Sw.) Schiffn.}

Marchesinia brachiata is widespread in tropical America, where it occurs on bark and rock in moist montane forest up to $3300 \mathrm{~m}$ elevation. A recent molecular study by Heinrichs et al. (2009) has shown that the species also occurs in Africa (St. Helena, Kenya); in addition it has been recorded from Hawaii (Gradstein 2012). Marchesinia brachiata has durable spores remaining viable for at least 3 weeks after drying (van Zanten \& Gradstein 1988) and it is likely, therefore, that the species attained its wide range by LDD.

\section{Mastigolejeunea auriculata (Wilson) Schiffn.}

Mastigolejeunea auriculata has variously been considered a neotropical, Afro-American and pantropical species (e.g., Schuster 1980; Gradstein 
et al. 1983; Thiers \& Gradstein 1989; Gradstein 1994; Gradstein et al. 2002). In Africa the species was known as M. carinata (Mitt.) Steph., and in Asia as M. humilis (Gottsche) Schiffn. Recent molecular and morphological work indicates that $M$. humilis is a distinct species and that M. auriculata does not occur in Asia (Wilson et al. 2007; Sukkharak et al. 2011). Consequently, M. auriculata is retained here as an Afro-American taxon. The species is widespread in tropical lowland regions of the two continents but lacks in Amazonia where it is replaced by M. plicatiflora (Spruce) Steph. (Gradstein 1994). The species grows on bark and rock in rather open habitats in rainforest regions and is rather drought-tolerant. It may therefore be expected that the species has durable spores, allowing for LDD. Nevertheless, good dispersibility of $M$. auriculata is contradicted by the absence of the species on the Galapagos Islands and the Lesser Antilles (Gradstein \& Weber 1982; Gradstein 1994).

\section{Metzgeria agnewiae Kuwah.}

According to Kuwahara (1986) and Costa (2008), M. agnewiae is widespread in the tropical mountains of $\mathrm{C}$ and S America and in E Africa, at 600-4000 $\mathrm{m}$ elevation. The species is recognized by having dimorphic thallus branches (attenuate and non-attenuate) which become blue upon drying, a 2-4 cells wide ventral costa, geminate or single hairs, and concave, disciform gemmae. So (2004) treated M. agnewiae as a synonym of the pantropical $M$. consanguinea Schiffn. but this synonymy was not accepted by Costa (2008) based on the narrower ventral costa in $M$. consanguinea, the lack of geminate hairs as well as several other distinctive features of the latter species.

\section{Metzgeria attenuata Steph.}

Metzgeria attenuata occurs scattered in the mountains of tropical America and E Africa, at 1100-3700 m elevation (Kuwahara 1986; Costa 2008). The species is rather similar to $M . a g$ newiae but the thallus does not become blue upon drying and the gemmae are flat and elongate. So (2004) treated M. attenuata as a synonym of the pantropical $M$. consanguinea Schiffn. but this synonymy was rejected by Costa (2008) because of the lack of blue coloration, the wider ventral costa and the constantly geminate hairs in M. attenuata.

\section{Microlejeunea globosa (Spruce) Steph.}

Microlejeunea globosa has an amphitropicaldisjunct distribution in the New World, occurring in SE Brazil, Paraguay and N Argentina, at the southern edge of the tropical belt, and again in Mexico and the southeastern U.S.A where it was described as Lejeunea cardotii Steph. (ReinerDrehwald 1994). The species is very rare in equatorial regions of tropical America; it was recently collected in a dry-evergreen, montane Acacia forest at $2300 \mathrm{~m}$ of Ecuador (Werner \& Gradstein 2009; A. Schäfer-Verwimp. pers. com.). The amphitropical range of $M$. globosa reflects its preference for dry environments; other liverwort species with amphitropical distributions (Chonecolea doellingeri, Cronisia fimbriata, Oxymitra incrassata, Riccia lamellosa) occur in arid habitats as well. Microlejeunea globosa grows on bark at low or high elevation depending on latitude and was recently detected new to Africa in Kenya, where it occurs on trees in urban areas at about $1700 \mathrm{~m}$ (ChuaPetiot \& Pócs 2003). In view of its occurrence in arid habitats, spores of $M$. globosa might be expected to be drought-resistant and suitable for LDD. This needs to be tested by spore germination experiments.

\section{Mnioloma caespitosum (Spruce) R. M. Schust.}

In the Neotropics, Mnioloma caespitosum (= Calypogeia caespitosa (Spruce) Steph.) occurs at rather low elevations in the tropical Andes, Guyana Highland and upper Rio Negro region, on shaded bark, humus and rock in undisturbed rainforest from sea level to about $1900 \mathrm{~m}$ (Gradstein \& Costa 2003; León et al. 2006). In Africa, the species has been detected by Pócs (2005) on Mt. Kilimanjaro, where it occurred in upper montane forest between 1800-2900 m, at significantly higher elevation than in the Neotropics. The occurrence of $M$. caespitosum in Africa comes as a surprise as the species is dioicous and usually 
sterile (sporophytes are unknown), and lacks any specialized asexual means of dispersal.

\section{Odontolejeunea lunulata (F. Weber) Schiffn.}

Odontolejeunea lunulata is one of the most common neotropical epiphyllous liverworts, occurring throughout tropical America on living leaves and also on bark, from sea level to $3000 \mathrm{~m}$. In Africa it was described as O. tortuosa (Lehm. \& Lindenb.) Steph. and is much less common, occurring mainly in montane environments, on the mainland as well as on the East African Islands, at (300-)1000-1700 m elevation (Teeuwen 1989; Wigginton 2004). Odontolejeunea lunulata can be autoicous or dioicous; in addition, asexual reproduction by cladia has been observed in neotropical plants.

\section{Odontoschisma variabile (Lindenb.} \& Gottsche) Trevis.

Fig. 1D

$=O$. africanum Steph., syn. nov.; O. atropurpureum Steph., syn. nov.; O. falcifolium Steph., syn. nov.

Odontoschisma variabile is the most common species of the genus Odontoschisma in tropical America, ranging from Cuba and Honduras to Bolivia and SE Brazil and growing on rotten wood, humus, soil or rock in rainforests, scrub and open vegetation, from almost sea level up to $4000 \mathrm{~m}$ elevation (Gradstein in prep.). The species has been described from the Neotropics under several names, including O. falcifolium Steph. and $O$. atropurpureum Steph. which are synonyms, and has been widely confused with $O$. denudatum (Nees) Dumort. which has a mainly holarctic distribution. Odontoschisma variabile also occurs in Africa where it was described as $O$. africanum Steph. The species is apparently rare in Africa and only known from about half a dozen collections from Tanzania, Malawi, S Africa and the Mascarenes, all of them from mid-montane environments between 1600-2000 m elevation. The species is dioicous (like all members in the genus) but is frequently fertile and copiously. produces gemmae.

Interestingly, van Zanten and Gradstein (1988) found that the spores of material from Colombian páramo identified as O. atropurpureum (van Zanten et al. 815) had very poor drought resistance and lost their ability of germination after one day of drying. The low spore viability would seem to contradict the Afro-American range of $O$. variabile (=O. atropurpureum). Re-examination of the material, however, showed that it was misidentified and belongs to a new species endemic to the páramos of Colombia (Gradstein in prep.).

32. Oxymitra incrassata Lindenb.

Fig. 1E

Oxymitra incrassata is the only species in the family Oxymitraceae together with the rare O. cristata Perold from South Africa (Bischler et al. 2005). In the New World it has a marked amphitropical distribution, occurring in C Mexico and again in Paraguay, Uruguay and N Argentina. In the Old World the species occurs in the mediterranean region northwards to $\mathrm{C}$ Europe and southwards to the Canary Islands and Socotra (Bischler et al. 2005; Kürschner 2006).

Oxymitra incrassata grows in dry areas on periodically moist sandy soil or clay at the base of rock in grasslands and in open woodlands or scrub, from sea level to $3000 \mathrm{~m}$ depending on latitude. The large spores of $O$. incrassata $(100-175 \mu \mathrm{m}$ in diam.) are presumably highly durable and programmed for surviving adverse environmental conditions, but because of their large size are probably not suitable for long distance dispersal by wind (van Zanten \& Gradstein 1988). Bird dispersal is a more likely cause of the disjunct range of this and other large-spored thalloid species. This should be verified by scrutinizing the feathers or feet of migratory birds, or by flying spores across long distances on birds.

\section{Plagiochila boryana Steph.}

Plagiochila boryana was long considered endemic to Madagascar and the Mascarenes (e.g. Grolle 1995). Recently, it has been shown that the species occurs also on the African mainland (Tanzania, Uganda), where it was collected by T. Pócs, and in South America (Bolivia, SE Brazil) where it had been described under several different names (Heinrichs 2002). The Afro-American range of the 
species has subsequently been confirmed by DNA sequencing (Heinrichs et al. 2005a). Plagiochila boryana is readily recognised by its robust size, lack of terminal branches, ampliate dorsal leaf bases, large leaf cells and, especially, the finely papillose cuticle. The species grows on bark, rock and soil in humid montane forests, at 2200-3800 m in South America, 1900-3000 m in East Africa and at much lower elevation (600-1900 m) on Réunion (Heinrichs 2002).

\section{Plagiochila corrugata (Nees) Mont. \& Nees}

By its strongly undulate-crispate leaf margins, $P$. corrugata is one of the most easily recognizable species of the genus Plagiochila. It is common in evergreen and semi-deciduous forests of the Mata Atlantica of Brazil, from sea level to $2300 \mathrm{~m}$ (Gradstein \& Costa 2003), and furthermore occurs in Bolivia, Paraguay and N Argentina. A recent morphological and molecular study (Heinrichs et al. 2004) demonstrated that $P$. corrugata also occurs in Africa where it was known as P. cambuena Steph. The African range of the species is rather restricted and includes Madagascar, the Comores and Tanzania where it occurs in lower montane environments, between 1000-1800 m.

\section{Plagiochila exigua (Taylor) Taylor}

Plagiochila exigua (= P. corniculata auct., fide Grolle 1983) occurs scattered in oceanic regions of the Holarctic and furthermore in tropical America and Africa (Schuster 1980, Inoue 1980: map). The holarctic range of the species includes the southern Appalachians, Macaronesia and coastal western Europe (N Spain to S Norway) and eastern Asia (Bhutan, China, Japan). In Africa, it has been recorded from the mountains of E Africa (several countries), S Africa and Réunion (Wigginton 2009). In the Neotropics P. exigua is known from the West Indies and the high mountains of Central America (Mexico, Costa Rica), northern Andes (Venezuela to Peru) and SE Brazil (Gradstein $\&$ Costa 2003). Inoue (1980) also recorded the species from Chile but molecular analysis showed that this material belongs to $P$. bicuspidata Gottsche (Groth et al. 2004).
Plagiochila exigua grows on bark and shaded moist rock in humid mountain forests, usually at high elevation $(1500-3500 \mathrm{~m})$ but on islands and in Europe sometimes at lower elevation. The wide holarctic-Afroamerican range of the species is unusual and needs further study by molecular analysis of populations of different parts of the range. Evidence from terpenoids has shown that populations from the Andes are chemically very different from those of the British Isles (see Groth et al. 2004).

\section{Plagiochila punctata (Taylor) Taylor}

Plagiochila punctata was long considered endemic to the Atlantic coast of Europe but a recent morphological and molecular study showed that the species is widespread in tropical America, where it was known as $P$. stolonifera Lindenb. \& Gottsche, as P. choachina Gottsche, and by several other names (Heinrichs et al. 2005a). In addition, the species was collected in East Africa by T. Pócs. Plagiochila punctata grows in humid tropical mountain forests and páramos, between 1000-4150 m elevation, and at lower elevation, from sea level to $1000 \mathrm{~m}$, along the Atlantic coast of Europe. The molecular data suggest that the species evolved in tropical South America in the late Tertiary and subsequently reached tropical Africa and W Europe by LDD (Heinrichs et al. 2004). In addition to spores, the species freely reproduces asexually by caducous leaves.

\section{Plagiochila stricta Lindenb.}

Plagiochila stricta is widespread in tropical America, occurring from Mexico to Bolivia and SE Brazil in humid montane forests, between 1000-2500 m elevation. Recently, the species has become known from Madagascar (Lindner et al. 2004) and Macaronesia (Rycroft et al. 2002) based on evidence from morphology, DNA sequences and terpenoid chemistry. As asexual propagules are unknown in this species, LDD to Africa and Macaronesia should have occurred by spores. Spore viability in $P$. stricta remains unknown, although van Zanten and Gradstein (1988) reported excellent spore viability in several neotropical Plagiochila 
species. The identifications of these Plagiochila specimens should be checked to see whether any Afro-American species were among them.

\section{Porella swartziana (F. Weber) Trevis.}

Porella swartziana is one of the most common and widespread species of this genus in tropical America, occurring on bark and rock in rather mesic lowland and montane forests up to about $3000 \mathrm{~m}$ elevation (So 2005). Recently, a population of P. swartziana has turned up from S Africa, which had been misidentified as $P$. capensis Steph. (Hentschel et al. 2007). The identity of the African material was confirmed by molecular analysis. The African record is rather unexpected because the species is dioicous and does not produce any special means of asexual reproduction (like other members of the genus). Indeed, transoceanic ranges in this genus are rare.

\section{Radula quadrata Gottsche}

The conspecificity of the neotropical Radula quadrata $(=R$. mollis Lindenb. \& Gottsche, fide Yamada \& Gradstein 1991) and the African R. recurvifolia Steph. was first suggested by Jones (1977) and subsequently proven by Yamada (1993). Radula quadrata is widespread in rather mesic forest habitats in tropical America and Africa, at elevations between (100-)500-3000 m depending on latitude, reaching downward to almost sea level in the U.S.A. and SE Brazil, at the northern and southern limits of its range.

\section{Radula voluta Taylor}

Radula voluta was long considered a rare, endemic species of the Atlantic coast of Great Britain until it was recorded from a few locations in the Appalachians, U.S.A., by Mescall et al. (1980) and Schuster (1980). Subsequently, its range was extended to tropical America, where it had been described as $R$. ramulina Taylor and is very common (Yamada \& Gradstein 1991), and to Africa where it was known as $R$. allamanoi Gola and is also common (Yamada 1993). Apparently, the European and N American populations were just isolated outliers of a wide tropical Afro-American range. Radula voluta not only has a wide geographical distribution but also a remarkably broad elevational range, growing on bark and rock and on litter in montane forests and páramo from 500 up to $4200 \mathrm{~m}$. The species occurs in very humid habitats and is one of the most robust species of the genus in America and Africa, being easily recognized in the field by its arcuate to almost pendent growth, its regularly pinnate habit and its bright yellowishgreen colour, which it usually retains in the dried condition. Van Zanten and Gradstein (1988) found that spores of Radula voluta remain viable for at least ten days after drying and sporelings for more than one month. These values are supportive of LDD of the species across the Atlantic.

\section{Riccardia amazonica (Spruce) Gradst.}

Riccardia amazonica is rather widespread in tropical S America and Africa, occurring on soil, shaded rock and rotten wood in lowland and montane rainforests from sea level up to $c a$ $2600 \mathrm{~m}$ elevation. The occurrence of the species in Africa, where it was described under many different names, was first suggested by Jones (1956) and confirmed by Meenks and Pócs (1985). The intercontinental range of $R$. amazonica was not supported by the experiments of van Zanten and Gradstein (1988), however, who found that spores of neotropical plants had very poor drought resistance, losing their capability of germination within a few hours of drying. Interestingly, the American and African plants seem to be different in sexuality, neotropical plants being dioicous whereas African populations are frequently monoicous (Meenks \& Pócs 1985; Wigginton 2004). In addition, Berrie (1966) found 10 chromosomes in a dioicous (male) plant from West Africa and 20 chromosomes in monoicous plants (Berrie 1966). The two karyotypes also differed in size, suggesting that the West African plants are sexually dimorphic. A molecular and morphological study of the intriguing relationships between the African and American populations of Riccardia amazonica is currently being carried out by C. Reeb (in prep.). 


\section{Riccia curtisii (Austin) Austin}

Riccia curtisii is a subtropical Afro-American species with an amphitropical distribution in the New World, occurring in the southern U.S.A. and again in SE Brazil, Paraguay, Uruguay and northern Argentina. In addition, there is a single record from the inner Neotropics: Costa Rica, San José, Montes de Oca (Bischler et al. 2005). In the Old World the species occurs in $\mathrm{C}$ and $\mathrm{S}$ Africa, and also in SW Asia and India. Riccia curtisii grows on moist sandy soil or clay in along trails, on river banks and in cultivated areas from sea level to $1400 \mathrm{~m}$. The large spores of $R$. curtisii $(85-150 \mu \mathrm{m}$ in diameter) should be durable and programmed for surviving adverse environmental conditions, but because of their large size should be less suitable for long-distance dispersal by wind (van Zanten \& Gradstein 1988).

\section{Riccia membranacea Gottsche \& Lindenb.}

Riccia membranacea, a species originally described from Mexico, is widespread in tropical America and Africa where it occurs on moist, compact soil in cultivated areas (gardens) and along lakes and rivers. The species occurs mainly in lowland areas but has been found to $1220 \mathrm{~m}$ elevation in W Africa and to over $2000 \mathrm{~m}$ in the Andes. The occurrence of $R$. membranacea in Africa was shown by Jones (1957) and overlooked by Gradstein et al. (1983).

\section{Symbiezidium barbiflorum (Lindenb.} \& Gottsche) Trevis.

Fig. 1F

Symbiezidium barbiflorum is widespread in the Neotropics, where it occurs as an epiphyte in lowland and montane rainforests up to $2800 \mathrm{~m}$ elevation. Recently, the species was reported new to Africa where it was collected in coastal forests of eastern Madagascar (Sass-Gyarmati \& Pócs 2002). The discovery of $S$. barbiflorum in Madagascar adds a further example of a peri-Afroamerican species, occurring in tropical America and the Indian Ocean islands but not on the mainland of Africa. This unusual disjunction is explained by the extinction of the species on the mainland of
Africa due to the drying-out of the African continent during the pleistocenic glaciations (Stearn 1971; Moore 1973).

45. Symphyogyna podophylla (Thunb.) Mont. \& Nees

Symphyogyna podophylla is widespread in tropical Africa and furthermore occurs in southern S America, SE Brazil and reaching northwards to the Andes of Colombia (Uribe 1999; Schaumann et al. 2003). It grows on humus-rich soil and rock in moist forests from sea level up to $3000 \mathrm{~m}$. The species has additionally been recorded from Australasia but Schaumann et al. (2003) showed that the Australasian populations belong to $S$. hymenophyllum (Hook.) Mont. \& Nees. The disjunct Andean occurrence of S. podophylla, in S Chile and Argentina and again in Colombia, is unusual and suggests that the species should be more widespread in the Andes.

\section{Syzygiella manca (Mont. 1856) Steph.}

$=$ S. geminifolia (Mitt. 1864) Steph., syn. nov.

Gradstein et al. (1983) considered the neotropical $S$. manca and the African $S$. geminifolia very similar and a vicariant species pair. Recent molecular evidence (Felberg et al. 2010) showed that an accession of S. manca from Ecuador (Nöske 163, det S.R. Gradstein) was indistinguishable from S. geminifolia. The evidence suggests that these two species are conspecific and should be called S. manca (oldest name). Syzygiella manca is rather widespread in tropical Africa whereas in tropical America it is only known from the northern Andes (Colombia to Peru).

\section{Tylimanthus laxus (Lehm. \& Lindenb.) Spruce}

Stephani (1898-1924) recognized seventeen species of Tylimanthus in tropical America but Burghardt and Gradstein (2008) could recognize only one species, the widespread and variable $T$. laxus occurring on bark, soil and rock in humid montane forests at (100-)1000-4000 m elevation. The species also occurs in tropical Africa, in similar 
environments, where it was known as T. ruwenzorensis Steph. The conspecificity of T. laxus and T. ruwenzorensis was first demonstrated by Stech et al. (2006) based on chloroplast DNA sequences. The latter authors also found a close relationship between T. laxus and two Macaronesian endemics, T. azoricus and T. madeirensis. These two species were subsequently also included in T. laxus by Burghardt and Gradstein (2008). As a result, $T$. laxus remains as the only genuine species of Tylimanthus in tropical America, Africa and Macaronesia. Two further African species, T. africanus Pears. and T. anisodontus (Hook.f. \& Tayl.) Mitt., are considered doubtful taxa.

\section{FURTHER POSSIBLE AFRO-AMERICAN SPECIES}

\section{Archilejeunea parviflora (Nees) Schiffn.}

The common neotropical Archilejeunea parviflora is morphologically very similar to $A$. $a b$ breviata (Mitt.) Vanden Bergh. and $A$. africana Steph. from tropical Africa (Wigginton 2004); possibly, the three are conspecific in which case the name $A$. parviflora is the oldest and correct name. The relationships of these taxa are currently being studied by Miss X.-Q. Shi from East China Normal University, Shanghai.

\section{Chonecolea andina Grolle \& Váňa}

Chonecolea andina from the high Andes of Peru and C. ruwenzorensis E. W. Jones from Uganda (Ruwenzori) are closely related (Jones 1985), and may be different at the subspecies level only. They differ in branching (purely lateral-intercalary in $C$. andina; lateral-intercalary and occasionally terminal in C. ruwenzorensis) and sexuality (dioicous in $C$. andina, paroicous in C. ruwenzorensis).

\section{Microlejeunea epiphylla Bischl.}

Microlejeunea epiphylla (= Lejeunea dimorphophylla R. M. Schust.) is widespread in tropical America, ranging from southern U.S.A. (Florida) to Ecuador and Brazil, and is morphologically quite variable (Schuster 1980). Ah-Peng and
Bardat (2011) described M. strasbergii sp. nov. from Réunion, which closely resembles $M$. epiphylla but differs by the subentire female bracteole (denticulate in M. epiphylla). Other characters seem to overlap. When the two species prove to be conspecific, Microlejeunea epiphylla would become another example of a peri-Afroamerican disjunction.

Riccia stricta (Lindenb.) Perold

The Riccia fluitans complex is represented in the Afro-American region by two common and widespread species, $R$. stricta in tropical Africa and R. stenophylla Spruce in tropical America. Based on their descriptions (Wigginton 2004; Bischler et al. 2005), the two species are morphologically very similar. When they prove to be conspecific, the correct name for the Afro-American species would be $R$. stricta.

\section{EXCLUDED SPECIES}

Aphanolejeunea exigua A. Evans

This species is now considered a variety of the pantropical Cololejeunea minutissima (Sm.) Schiffn. The taxonomy and distribution of this widespread and morphologically variable species needs further study.

\section{Brachiolejeunea laxifolia (Taylor) Schiffn.}

Brachiolejeunea laxifolia is a common and widespread montane-neotropical species (van Slageren 1985; Gradstein 1994). The species has additionally been recorded from São Tomé, W Africa, as B. thomeensis Steph. (van Slageren 1985), based on a very scanty and poorly labelled specimen. Since no further African material has turned up, in spite of much recent collecting activity on São Tomé and elsewhere (e.g., Müller et al. 2011; Sérgio \& Garcia 2011; Wigginton 2004), the occurrence of B. laxifolia in Africa is considered doubtful. The probable absence of B. laxifolia in Africa concurs with the low viability of the spores of this species, which lost their ability of germination within five days after drying (van Zanten \& Gradstein 1988). 
Chiloscyphus vermicularis (Lehm.) Hässel

$=$ Clasmatocolea vermicularis (Lehm.) Grolle

This species was listed as an Afro-American species by mistake as Engel (1980) had already shown that the species is pantemperate and also occurs in Australasia. In addition, the species occurs in Papua New Guinea (Piippo 1992).

\section{Cololejeunea cardiocarpa (Nees \& Mont.) R.M. Schust.}

Gradstein et al. (1983) cited a doubtful record from New Caledonia in addition to its Afro-American range. The $\mathrm{N}$ Caledonian record was based on Physocolea savesiana Steph. (N. Caledonia, Theophile Savès 242), which Tixier (1979) placed in synonymy of $C$. cardiocarpa with the remark 'origin douteuse'. Pócs (pers. com.) found that the New Caledonian specimen represents typical C. cardiocarpa. Moreover, C. cardiocarpa has since been detected in Queensland, Australia (Thiers 1988), where it is actually quite common (T. Pócs, pers. com.), and in S India (Asthana \& Srivasta 2003). It is therefore surprising that the species is not known from Malesia, not even from New Guinea.

\section{Herbertus subdentatus (Steph.) Fulford}

Gradstein et al. (1983) recorded the neotropical Herbertus subdentatus (Steph.) Fulford from Africa but Hodgetts $(2003,2008)$ showed that the African material belonged to $H$. dicranus (Taylor) Trevis., a species widespread in Asia and Africa and not known in the Neotropics. Herbertus subdentatus is now considered a synonym of $H$. acanthelius Spruce (Feldberg \& Heinrichs 2006, as H. juniperoideus subsp. acanthelius), a common neotropical species from high elevations in the Andes and Costa Rica.

Heteroscyphus integrifolius (Lehm. \& Lindenb.) Fulford

According to Grolle (1995), the African report of this southern South American species is erroneous.

\section{Metzgeria albinea Spruce}

Metzgeria albinea has variously been treated as a strictly neotropical (So 2002, 2004), AfroAmerican (Costa 2008) or pantropical species (Kuwahara 1986). None of these authors, however, presented a detailed study of the morphological variation and taxonomy of the species throughout its whole range. African populations of $M$. albinea, earlier described as M. thomeensis Steph., possess marginal hairs arising single or in pairs and therefore So (2004) assigned these plants to M. furcata L. However, this treatment is unconvincing as $M$. furcata normally has single hairs and a 3-4 cells wide ventral costa. The possibility that the African plants represent phenotypes of $M$. albinea with poorly developed hairs should not be ruled out. Asian populations were described as M. foliicola Schiffn. and were treated as M. albinea by Kuwahara $(1984,1986)$ and again as M. foliicola by So (2002), based on having somewhat larger and \pm thick-walled thallus cells. However, no measurements of cell sizes in the two species were provided by the latter author. In view of the large variation in cell areolation observed in neotropical $M$. albinea (Costa 2008), it seems that M. foliicola Schiffn. and $M$. albinea are inseparable. Plants with short hairs and rather small and thick-walled cells were separated as M. australis Steph. by Kuwahara (1984, 1986), but Costa (2008) included these plants in the variation of M. albinea. Earlier, So (2002) had shown that the true M. australis has falcate hairs and is a synonym of $M$. leptoneura Spruce.

The available data are suggestive of a pantropical distribution of $M$. albinea, as advocated by Kuwahara (1984). A careful study of the morphological variation of the species on a world-wide basis coupled with molecular analysis, are needed to clarify the range of the species.

\section{Pycnolejeunea contigua (Nees) Grolle}

In her monograph of the genus Pycnolejeunea, He (1999) showed that P. contigua (treated as Afro-American by Gradstein et al. 1983) occurs in Indonesia where it was known as P. bancana 
Steph. As a result, the species has become pantropical in distribution.

\section{Radula boryana (F. Weber) Nees}

According to Yamada (in Yamada \& Gradstein 1991), Radula boryana is restricted to Africa and does not occur in tropical America. Neotropical material identified as $R$. boryana differs from the latter species in habit and lobule morphology and belongs to $R$. gottscheana Taylor.

ACKNOWLedgments. This paper is dedicated to Professor Tamás Pócs at the occasion of his $80^{\text {th }}$ birthday and as a token of my gratitude for many years of fruitful cooperation in bryology. I am very grateful to Ricardo Rico (Mérida) for information on Aneura latissima, to Alfons Schäfer-Verwimp (Herdwangen-Schönach) for information on Colura ornithocephala and Microlejeunea globosa and to Támas Pócs (Eger) for literature and information on Cololejeunea cardiocarpa; furthermore to Martin Wigginton (Warmington), Jiří Váňa (Prague) and Jairo Patiño (La Laguna) for comments and corrections on the manuscript; and to Didier Geffard-Kuriyama (MNHN Paris, UMS 2700/Pôle dessin) for preparing the figure for publication.

\section{REFERENCES}

Ah-Peng C. \& BARDAT J. 2011. Microlejeunea strasbergii sp. nov. (Lejeuneaceae) from Réunion Island (Mascarenes). Bryologist 114: 668-673.

ARNELL S. 1963. Hepaticae of South Africa. Norsted and Söner, Stockholm.

Asthana G. \& SRIVASTAVA S. C. 2003. Indian Cololejeunea. Bryophyt. Biblioth. 60: 1-155.

Berrie G. K. 1966. Polyploidy in some West African species of Riccardia Gray. Rev. Bryol. Lichénol. 34: 302-308.

BischleR H. 1984. Marchantia L.: The New World species. Bryophyt. Biblioth. 26: 1-228.

BISCHLER H. 1989. Marchantia L.: The Asiatic and Oceanic species. Bryophyt. Biblioth. 38: 1-317.

BISCHLER H. 1993. Marchantia L.: The European and African taxa. Bryophyt. Biblioth. 45: 1-129.

BISCHLER H. 2005. Liverworts of the Mediterranean: ecology, diversity and distribution. Bryophyt. Biblioth. 61: 1-252.

Bischler H., Gradstein S. R., Jovet-Ast J., LONG D. G. \& SAlaZAR AlLEN N. 2005. Marchantiidae. Flora Neotr. Monogr. 97: 1-262.
BuRghaRdT M. \& GRADSTEIN S. R. 2008. A revision of Tylimanthus in tropical America, Africa and Macaronesia. Fieldiana, Bot. 47: 199-210.

Burghardt M., GRAdSTEIN S. R. \& VÁŇA J. 2006. Discovery of the African liverwort genus Cephalojonesia (Cephaloziellaceae) in Mexico. J. Hattori Bot. Lab. 100: 35-39.

CARLQUist S. 1983. Intercontinental dispersal. Sonderb. $\mathrm{Na}$ turwiss. Vereins Hamburg 7: 37-47..

Chunh-Petiot M. S. 2003. Mosses, liverworts \& hornworts of Kenya. Nairobi, Kenya.

ChuAh-Petiot M. S. \& Pócs T. 2003. East African bryophytes XIX. A contribution to the bryoflora of Kenya. Acta Bot. Hung. 54: 53-64.

Churchill S. P., Sanjines N. N. \& Aldana C. 2009. Catálogo de las briofitas de Bolivia. Missouri Botanical Garden, St. Louis.

Costa D. P. 2008. Metzgeriaceae (Hepaticae). Fl. Neotrop. Monogr. 202: 1-169.

Crandall-Stotler B. J., Stotler R. E. \& Long D. G. 2009. Phylogeny and classification of the Marchantiophyta. Edinburgh J. Bot. 66: 155-198.

CRUDEN R. W. 1966. Birds as agents of long-distance dispersal for disjunct plant groups of the temperate Western Hemisphere. Evolution 20: 517-532.

DAUPHIN C. 2003. Ceratolejeunea. Fl. Neotrop. Monogr. 90: $1-86$.

DAUPHIN C. 2005. Catalogue of Costa Rican Hepaticae and Anthocerotae. Trop. Bryol. 26: 141-218.

Demaret F. \& VAnden Berghen C. 1948. Frullania arecae (Spreng.) Gottsche et F. ecklonii (Spreng.) Gottsche et Lindenb. Bull. Jard. Bot. État Bruxelles 19: 73-84.

Devos N. \& VANDERPOORTEN A. 2009. Range disjunctions, speciation, and morphological transformation rates in the liverwort genus Leptoscyphus. Evolution 63: 779-792.

ENGEL J. J. 1978. A taxonomic and phytogeographic study of Brunswick Peninsula (Strait of Magellan): Hepaticae and Anthocerotae. Fieldiana, Bot. 41: 1-319.

ENGEL J. J. 1980. A monograph of Clasmatocolea (Hepaticae). Fieldiana Bot. 3: 1-229.

Engel J. J. \& Smith Merrill G. L. 2004. A taxonomic and phylogenetic study of Telaranea (Lepidoziaceae). Fieldiana, Bot. 44: 265.

FELDBERG K. \& HeINRICHS J. 2006. A taxonomic revision of Herbertus (Jungermanniidae: Herbertaceae) in the Neotropics based on nuclear and chloroplast DNA and morphology. Bot. J. Linn. Soc. 151: 309-332.

Feldberg K., VÁŇa J., Schulze C., Bombosch A. \& HeinRICHS J. 2011. Morphologically similar but genetically distinct: on the differentiation of Syzygiella concreta and S. perfoliata (Adelanthaceae subfam. Syzygielloideae). Bryologist 114: 686-695. 
Feldberg K., Hentschel J., Wilson R., Rycroft D. S., GlenNY D. \& HeINRICHS J. 2007. Phylogenetic biogeography of the leafy liverwort Herbertus (Jungermanniales, Herbertaceae) based on nuclear and chloroplast DNA sequence data: correlation between genetic variation and geographic distribution. J. Biogeogr. 34: 688-689.

FeldBerg K., VÁŇA J, LONG D. G., ShaW J., Hentschel J. \& HeInRICHS J. 2010. A phylogeny of Adelanthaceae (Jungermanniales, Marchantiophyta) based on nuclear and chloroplast DNA markers, with comments on classification, cryptic speciation and biogeography. Molec. Phylogenet. Evol. 55: 293-304.

FrEY W. 2009. Syllabus of Plant Families. Part 3: Bryophytes and seedless vascular plants. Borntraeger Verlag, Stuttgart, Berlin.

FULFORD M. H. 1951. Distribution patterns of the genera of leafy Hepaticae of South America. Evolution 5: 243-264.

FULFORD M. H. 1963-1976. Manual of the leafy Hepaticae of Latin America Parts - Parts I-IV. Mem. New York Bot. Gard. 11: 1-535.

FULFORD M. H. 1976. Manual of the leafy Hepaticae of Latin America - Part IV. Mem. New York Bot. Gard. 11: 393-535.

GiancotTi C. \& Vital D. 1989. Lejeunea capensis Gott. (Hepaticae: Lejeuneaceae) disjunct between South America and Africa. Bryologist 92: 305-307.

GRADSTEIN S. R. 1975. A taxonomic monograph of the genus Acrolejeunea. Bryophyt. Biblioth. 4: 1-216.

GRADSTEIN S. R. (ed.) 1985. Contributions to a monograph of the Lejeuneaceae subfam. Ptychanthoideae. Nova Hedwigia Beih. 80: 1-253.

GRADSTEIN S. R. 1994. Lejeuneaceae: Ptychantheae, Brachiolejeuneae. Flora Neotr. Monogr. 62: 1-216.

GRADSTEIN S. R. 1997. Hepatophyta, Anthocerotophyta. In: J. Boggan, V. FunK, C. Kelloff, M. Hoff, G. Cremers \& C. FEUILLET (eds), Checklist of the plants of the Guianas, pp. 9-15. Smithsonian Institution, Washington.

GradsTEIN S. R. 2006. The lowland cloud forest of French Guiana - a liverwort hotspot. Cryptog. Bryol. 27: 141-152.

GRADSTEIN S. R. 2012. An overview of the genus Marchesinia (Lejeuneaceae), with special attention to the species described from Asia and Oceania. Polish Bot. J. 57: 69-79.

Gradstein S. R. 2013. Notes on Early Land Plants Today. 26. Miscellaneous new synonyms in liverworts. Phytotaxa 81: 3-7.

GRADSTEIN S. R. \& CosTA D. P. 2003. The liverworts and hornworts of Brazil. Mem. New York Bot. Gard. 87: 1-317.

Gradstein S. R. \& HekKing W. H. A. 1979. Studies on Colombian Cryptogams IV. A catalogue of the Hepaticae of Colombia. J. Hattori Bot. Lab. 45: 93-144.
Gradstein S. R. \& HeKKING W. H. A. 1989. A catalogue of the bryophytes of the Guianas. I. Hepaticae and Anthocerotae. J. Hattori Bot. Lab. 66: 197-230.

Gradstein S. R. \& IlkiU-Borges A. L. 2009. Guide to the plants of Central French Guiana. Part 4. Liverworts and hornworts. Mem. New York Bot. Gard. 76(4): 1-170.

Gradstein S. R. \& URIBE J. Accepted. Marchantiophyta. In: R. Bernal, S. R. Gradstein \& M. Celis (eds), Catalogue of the Plants of Colombia.

GRADSTEIN S. R. \& VÁŇA J. 1987. On the occurrence of Laurasian liverworts in the Tropics. Mem. New York Bot. Gard. 45: 388-425.

GRADSTEIN S. R. \& VÁŇA J. 1999. On the taxonomy of Kymatocalyx and Stenorrhipis (Cephaloziellaceae). Haussknechtia Beih. 9: 155-170.

GRADSTEIN S. R. \&WEBER W. A. 1982. The bryogeography of the Galapagos Islands. J. Hattori Bot. Lab. 52: 127-152.

Gradstein S. R., Churchill S. P. \& Salazar Allen N. 2001. Guide to the bryophytes of Tropical America. Mem. New York Bot. Gard. 86: 1-577.

Gradstein S. R., Cleef A. M. \& Fulford M. H. 1977. Oil body structure and ecological distribution of selected species of Andean Jungermanniales. Proc. Kon. Ned. Akad. Wetensch., Ser. C, Biol. Med. Sci. 80: 377-420.

Gradstein S. R., Meneses R. I. \& Allain Arbe B. 2003. Catalogue of the Hepaticae and Anthocerotae of Bolivia. J. Hattori Bot. Lab. 93: 1-65.

Gradstein S. R., PÓCS T. \& VÁŇA J. 1983. Disjunct Hepaticae in Tropical America and Africa. Acta Bot. Hung. 29: $127-171$.

Gradstein S. R., He X.-L., PiIPPo S. \& Mizutani M. 2002. Bryophyte flora of the Huon Peninsula, Papua New Guinea LXVIII. Lejeuneaceae subfamily Ptychanthoideae (Hepaticae). Acta Bot. Fennica 174: 1-88.

GROLLE R. 1962. Monographie der Lebermoosgattung Leptoscyphus Mitt. Nova Acta Leop. 25: 1-143.

Grolle R. 1978. Die Lebermoose der Seychelles. Wiss. Z. Friedrich-Schiller-Univ. Jena, Math.-Naturwiss. Reihe 27: $1-17$.

Grolle R. 1979a. Miscellanea hepaticologica 171-180. J. Bryol. 10: 263-272.

GROLLE R. 1979b. Miscellanea hepaticologica 181-190. J. Hattori Bot. Lab. 45: 173-183.

GROLLE R. 1983. Hepatics of Europe including the Azores - An annotated list of species, with synonyms from the recent literature. J. Bryol. 12: 403-459.

Grolle R. 1995. The Hepaticae and Anthocertae of the East African Islands - An annotated catalogue. Bryophyt. Biblioth. 48: 1-178.

Grolle R. \& VANDEN Berghen C. 1995. Un genre nouveau 
pour la famille des Cephaloziellaceae: Cephalojonesia. Rev. Bryol. Lichénol. 37: 763-767.

Groth H., HARTMANN F. A., WiLson R. \& HeinRICHS J. 2004. NrITS sequences and morphology indicate a synonymy of the Patagonian Plagiochila rufescens Steph. and the Central American Plagiochila bicuspidata Gottsche. Cryptog. Bryol. 25: 19-28.

Groth H., Lindner M., Wilson R., Hartmann F. A., SCHMUll M., GRAdSTEIN S. R. \& HeINRICHS J. 2003. Biogeography of the genus Plagiochila (Hepaticae): natural species groups span several floristic kingdoms. J. Biogeogr. 30: 965-978.

Harrington A. J. \& Jones E. W. 2004. Distribution and habitats of liverworts in West Africa. In: M. J. WigGINTON (ed.), E. W. Jones's Liverwort and Hornwort Flora of West Africa, pp. 27-29. National Botanica Garden, Meise, Belgium.

HaRtMann F. A., Wilson R., GRADSTEIn S. R., SCHNEIDER H. \& HeInRICHS J. 2006. Testing hypotheses on species delimitation and disjunctions in the liverwort Bryopteris (Lejeuneaceae). Int. J. Pl. Sci. 167: 1205-1214.

HÄSSEl DE MENEndeZ G. G. 2001. Revision of the genus Leptoscyphus Mitt. (Hepatophyta) from southern South America. J. Hattori Bot. Lab. 91: 205-227.

HE X.-L. 1999. A taxonomic monograph of the genus Pycnolejeunea (Lejeuneaceae, Hepaticae). Acta Bot. Fenn. 163: $1-77$.

HE X.-L. \& Grolle R. 2001. Xylolejeunea, a new genus of the Lejeuneaceae (Hepaticae) from the Neotropics, Madagascar and the Seychelles. Ann. Bot. Fenn. 38: 25-44.

HEINRICHS J. 2002. A taxonomic revision of Plagiochila sect. Hylacoetis, sect. Adiantoideae and sect. Fuscoluteae in the Neotropics. Bryophyt. Biblioth. 58: 1-184.

HEINRICHS J., KLUGMANN F. A., HENTSCHEL J. \& SCHNEIDER H. 2009. DNA taxonomy, cryptic speciation and diversification of the Neotropical-African liverwort, Marchesinia brachiata (Lejeuneaceae, Porellales). Molec. Phylogenet. Evol. 53: 113-121.

HeINRICHS J., LindNER M., GROTH H. \& RENKER C. $2005 \mathrm{a}$. Distribution and synonymy of Plagiochila punctata (Taylor) Taylor, with hypotheses on the evolutionary history of Plagiochila sect. Arrectae (Plagiochilaceae, Hepaticae). Pl. Syst. Evol. 250: 105-117.

Heinrichs J., Groth H., Lindner M., Renker C., Pócs T. \& PRÖSCHOLD T. 2004. Intercontinental distribution of Plagiochila corrugata (Plagiochilaceae, Hepaticae) inferred from nrDNA ITS sequences and morphology. Bot. J. Linn. Soc. 146: 469-481.

HeInRICHS J., LindNER M., GRAdSTEIN S. R., GROTH H., Buchbender V., SOlga A. \& Fischer E. 2005b. Origin and subdivision of Plagiochila (Jungermanniidae: Plagiochilaceae) in tropical Africa based on evidence from nuclear and chloroplast DNA sequences and morphology. Taxon 54: 317-333.

HeinRichs J., Lindner M., Groth H., Hentschel J., FeldBERG K., RENKER C., ENGEL J. J., VON KONRAT M., LONG D. G. \& SCHNEIDER H. 2006. Goodbye or welcome Gondwana? - insights into the phylogenetic biogeography of the leafy liverwort Plagiochila with a description of Proskauera, gen. nov. (Plagiochilaceae, Jungermanniales). Pl. Syst. Evol. 258: 227-250.

Hentschel J., Zhu R.-L., Long D. G., Davidson P. G., SCHNeIder H., GRAdSTEIN S. R. \& HeInRICHS J. 2007. A phylogeny of Porella (Porellaceae, Jungermanniopsida) based on nuclear and chloroplast DNA sequences. Molec. Phylogenet. Evol. 45: 693-705.

Herzog T. 1926. Geographie der Moose. G. Fischer, Jena.

HodGetTs N. 2003. Some synonyms of Herbertus dicranus (Gottsche et al.) Trevis. J. Bryol. 25: 138-140.

HodGETTS N. 2008. A morphological revision of the genus Herbertus S.Gray (Herbertaceae, Marchantiophyta) in Africa, including the East African islands. J. Bryol. 30: 239-263.

ILKIU-BorgeS A. L. 2000. Lejeuneaceae (Hepaticae) da Estação Científica Ferreira Penna, Caxiuanã, Município de Melgaçao, Pará. Dissertação de Mestrado. Faculdade de Ciencias Agrárias do Pará, Belém.

ILKIU-BORGES A. L. 2006. A taxonomic monograph of the genus Prionolejeunea (Lejeuneaceae, Jungermanniopsida). Cuvillier, Göttingen.

InOUE H. 1980. Notes on the Plagiochilaceae, X. Plagiochila corniculata (Dum.) Dum. and its allies. Bull. Natl. Sci. Mus., Tokyo, B 6: 115-124.

JONES E. W. 1956. African hepatics XI. The genus Riccardia in Tropical Africa. Trans. Brit. Bryol. Soc. 3: 74-84.

JONES E. W. 1957. African hepatics XIII. The Ricciaceae in Tropical Africa. Trans. Brit. Bryol. Soc. 3: 208-227.

JONES E. W. 1976. African hepatics XXIX. Some new or little-known species and extensions of range. J. Bryol. 9: $43-54$.

JONES E. W. 1977. African hepatics XXX. The genus Radula Dumortier. J. Bryol. 9: 461-504.

JONES E. W. 1985. African hepatics XXXV. Some or littleknown species and noteworthy extensions of range. J. Bryol. 13: 385-398.

Jovet-Ast S. 1980. La section Oidocorys S. J.-A. du genre Colura Dum. est-elle âgée de plus de 100 millions d'années? Cryptog. Bryol. Lichénol. 1: 277-287.

KRUIJT R. 1985. A preliminary revision of the genus Dicranolejeunea (Spruce) Schiffn. Nova Hedwigia Beih. 80: $155-163$.

KRUIJT R. 1988. A monograph of the genera Dicranolejeunea and Acanthocoleus. Bryophyt. Biblioth. 36: 1-136. 
KRUIJT R. \& GRADSTEIN S. R. 1986. Studies on Lejeuneaceae subfam. Ptychanthoideae X. On Brachiolejeunea phyllorhiza (Nees) comb. nov. Nova Hedwigia 43: 299-309.

KÜRSCHNER H. 2006. A bryophyte flora of Socotra Island, Yemen. Englera 28: 97-162.

KuWAhara Y. 1984. Synopsis of sect. Biseria Kuw., subgen. Metzgeria Kuw., gen. Metzgeria Raddi (Hepaticae). Hikobia 9: $31-42$.

KUWAHARA Y. 1986. The Metzgeriaceae of the Neotropics. Bryophyt. Biblioth. 28: 1-254.

LAVOCAT-BERNARD E. \& SCHÄFER-VERWIMP A. 2011. Checklist of the bryophytes of the Guadeloupe archipelago and Martinique (French West Indies). Cryptog. Bryol. 32: 232-272.

LeÓn-YÁnez S., Gradstein S. R. \& Wegner C. 2006. Hepaticas y Antoceros del Ecuador. Herbario QCA, Quito.

LINDNER M., PÓCS T. \& HEINRICHS J. 2004. On the occurrence of Plagiochila stricta on Madagascar, new to Africa. $J$. Hattori Bot. Lab. 96: 261-271.

MeEnKS J. \& Pócs T. 1985. East African bryophytes IX. Aneuraceae. Abstr. Bot. (Budapest) 9: 79-98.

Mescall Y. M., Yamada K. \& Smith D. K. 1980. Radula voluta Tayl. new for North America. Misc. Bryol. Lichenol. 8: $153-154$.

Moore H. 1973. Palms in the tropical forest ecosystems of Africa and South America. In: B. J. MEgGers, E. AYENSU \& W. D. DUCKWORTH (eds), Tropical forest ecosystems in Africa and South America: a comparative review, pp. 63-88. Smithsonian Institution, Washington.

MÜLLER F. \& PÓCS T. 2007. A contribution to the knowledge of epiphyllous bryophytes of Bioko Island (Equatorial Guinea), including additional remarks on non-epiphyllous species. J. Bryol. 29: 91-94.

Müller F., Pócs T. \& Shevock J. 2011. Additions to the liverwort and hornwort flora of São Tomé and Príncipe. Trop. Bryol. 33: 19-22.

O’SHEa B. J., Wigginton M. J., BRUgGEMAN-NANNENGa M. A., Hedenäs L., Matcham H. W., Frahm J.-P., Porley R. D., Ellis L. T., Watling M. C., Bates J. E. \& VÁŇA J. 2003. Bryophytes of Uganda, 6. New and additional records, 3. Trop. Bryol. 24: 161-168.

PIIPPO S. 1992. Bryophyte flora of the Huon Peninsula, Papua New Guinea. LI. Additions and corrections to the Geocalycaceae (Hepaticae). Ann. Bot. Fenn. 29: 243-248.

Pócs T. 1976. Correlation between the tropical African and Asian bryofloras. I. J. Hattori Bot. Lab. 41: 95-106.

Pócs T. 1990. The exploration of the East African bryoflora. Trop. Bryol. 2: 177-191.

Pócs T. 1992. Correlation between the tropical African and Asian bryofloras. II. Bryobrothera 1: 35-47.

Pócs T. 1995. East African Bryophytes XIV. Hepaticae from the Indian Ocean islands. Fragm. Florist. Geobot. 40: 251-277.

Pócs T. 1999. Trachylejeunea grolleana, a new representative of the Neotropical subgenus Hygrolejeuneopsis in Madagascar. Haussknechtia Beih. 9: 283-290.

Pócs T. 2005. East African bryophytes XX. Observations on some Calypogeiaceae. Academiae Paedagogicae Agriensis Sectio Biologiae 32: 29-35.

Pócs T. 2010. East African bryophytes XXXVI. New records from Mayotte (Maore) Island (French Comoro). Acta Bryolichenol. Asiat. 3: 105-114.

Pócs T. 2011. East African bryophytes XXIX. The Ceratolejeunea species of the Indian Ocean islands. Polish Bot. J. 56: $131-153$.

REINER-DREHWALD M. E. 1994. Sobre Microlejeunea globosa (Spruce) Steph. y la fragmentación del tallo. Candollea 49: 225-232.

REINER-DREhWALD M. E. \& GodA A. 2000. Revision of the genus Crossotolejeunea (Lejeuneaceae, Hepaticae). J. Hattori Bot. Lab. 89: 1-54.

REINER-DREHWALD M. E. \& SCHÄFER-VERWIMP A. 2008. On Inflatolejeunea, Lejeunea species with eplicate perianths and Lejeunea talamancensis sp. nov. from Costa Rica (Lejeuneaceae). Nova Hedwigia 87: 387-420.

RENNER S. S. 2005. Relaxed molecular clocks for dating historical plant dispersal events. Trends in Plant Science 10: $550-558$.

RICO R. R. 2011. Methods for clearing and rehydration in thalloid liverworts. Trop. Bryol. 33: 12-18.

Rycroft D. S., Cole W. J., Heinrichs J., Groth H. \& Holz I. 2002. Phytochemical, morphological and molecular evidence for the occurrence of the neotropical liverwort Plagiochila stricta in the Canary Islands, new to Macaronesia. Bryologist 105: 363-372.

SASs-Gyarmati A. \& Pócs T. 2002. A second species of Symbiezidium from Africa Cryptog. Bryol. 23: 31-39.

SCHÄFER-VERWIMP A. 1992. New or interesting records of Brazilian bryophytes, III. J. Hattori Bot. Lab. 71: 55-68.

SCHÄFER-VERWIMP A. 2009. A checklist of the liverworts and hornworts of Dominica, West Indies. Cryptog. Bryol. 31: 313-415.

Schaumann F., Frey W., Hässel de Menendez G. G. $\&$ PFEIFFER T. 2003. Geomolecular divergence in the Gondwanan dendroid Symphyogyna complex. Flora 198: 404-412.

Schuette S. \& StotLer R. 2005. A conspectus of the liverwort genus Jensenia in Latin America. J. Hattori Bot. Lab. 97: 299-308.

Schuster R. M. 1969. The Hepaticae and Anthocerotae of North America, II. Columbia University Press, New York. 
SCHUSTER R. M. 1980. The Hepaticae and Anthocerotae of North America, IV. Columbia University Press, New York.

SCHUSTER R. M. 1990. Origins of neotropical leafy Hepaticae. Trop. Bryol. 2: 239-264.

SCHUSTER R. M. 1995. Phylogenetic and taxonomic studies of Jungermanniidae, III. Calypogeiaceae. Fragm. Florist. Geobot. 40: 825-888.

SCHUSTER R. M. 2002. Austral Hepaticae II. Nova Hedwigia Beih. 119: 1-606.

SÉRgIO C. \& GARCIA C. 2011. Bryophyte flora of São Tomé and Príncipe Archipelago (West Africa): Annotated catalogue. Cryptog. Bryol. 32: 145-196.

So M. L. 2002. Metzgeria (Marchantiophyta) in Australasia and the Pacific. New Zealand J. Bot. 40: 603-627.

So M. L. 2004. Metzgeria (Marchantiophyta) in Africa. New Zealand J. Bot. 42: 271-292.

So M. L. 2005. Porella (Porellaceae, Marchantiopyhta) in Latin America. New Zealand J. Bot. 43: 301-321.

Söderstrom L., Hagborg A., VÁŇA J. \& von Konrat M. 2011. Land of wood and water: A checklist of liverworts and hornworts of Jamaica. Bryologist 114: 67-91.

SÖDERSTRÖM L., VÁŇA J., HAgBorg A. \& VON KonRAT M. 2013. Notes on Early Land Plants Today. 31. Lophonardia replaces Hypolophozia (Cephaloziellaceae, Marchantiophyta). Phytotaxa 81: 19-21.

Spruce R. 1885. Hepaticae Amazonicae et Andinae. Aneura. Trans. \& Proc. Bot. Soc. Edinburgh 15: 540-551.

STEARN W. T. 1971. A survey of the tropical genera Oplionia and Psilanthele (Acanthaceae). Bull. Brit. Mus. (Nat. Hist.), Bot. 4: 259-323.

Stech M., Osman S., SiM-Sim M. \& FreY W. 2006. Molecular systematics and biogeography of the liverwort genus Tylimanthus (Acrobolbaceae). Nova Hedwigia 83: 17-30.

Stephani F. 1898-1924. Species Hepaticarum, 6 vols. Georg $\&$ Cie, Genève \& Bale.

Stotler R. \& Crandall-Stotler B. 1999. The hepatic genus Bryopteris (Lejeuneaceae) revisited. Bryobrothera 5: 213-220.

Stotler R., Salazar Allen N., Gradstein S. R., McGuiness W., Whittemore A., Chung C. 1996. A checklist of the Hepatics and Anthocerotes of Panama. Trop. Bryol. 15: 167-195.

SukkharaK P., Gradstein S. R. \& Stech M. 2011. Phylogeny, taxon circumscriptions and character evolution in the core Ptychanthoideae. Taxon 60: 1607-1622.

SWARTZ O. 1788. Nova genera et species plantarum seu Prodromus. Holm, Uppsala. [reprint 1962, J. Cramer, Weinheim].
TEEUWEN M. 1989. A revision of the genus Odontolejeunea. Nova Hedwigia 48: 1-32.

THIERS B. M. 1988. The Australian species of Cololejeunea. Nova Hedwigia Beih. 90: 113-146.

ThIERs B. M. \& GRADSTEIN S. R. 1989. Lejeuneaceae of Australia I: subfamily Ptychanthoideae. Mem. New York Bot. Gard. 52: 1-79.

TIXIER P. 1979. Contribution à l'étude du genre Cololejeunea. Les Cololejeunoidées de Nouvelle Caledonie. Essai monographique. Nova Hedwigia 31: 721-787.

URIBE, J. 1999. Nuevo registro del género Symphyogyna para Colombia. Revista Acad. Colomb. Ci. Exact. 23(Suplemento especial): 119-121.

VÁŇA J. \& ENGEL J. J. 2013. The liverworts and hornworts of the Tristan da Cunha group. Mem. New York Bot. Gard. 105: $1-138$.

VÁŇA J., Söderström L., Hagborg A. \& VON KonRat M. 2013. Early Land Plants Today 20. New synonyms in Gymnocoleopsis (Cephaloziellaceae, Marchantiophyta). Phytotaxa 76: 41-42.

VANDEN BERGHEN C. 1951. Contribution à l'étude des espèces africaines du genre Ceratolejeunea (Spruce) Schiffn. Bull. Jard. Bot. État Bruxelles 21: 61-81.

VAnden Berghen C. 1972. Hépatiques et Anthocérotées. In: J.-J. Symoens (ed.), Résultats scientifiques. Exploration hydrobiologique du bassin du lac Bangweolo et du Luapula. 8(1). Cercle Hydrobiologique de Bruxelles, Bruxelles.

VAnderpoorten A., Gradstein S. R., CARINe M. A. \& Devos N. 2009. The ghosts of Gondwana and Laurasia in modern liverwort distributions. Biol. Rev. Cambridge Philos. Soc. 85: $471-487$.

VANDERPOORTEN A., SCHÄFER-VERWIMP A., HEINRICHS J., DEvos N. \& LONG D. 2010. The taxonomy of the leafy liverwort genus Leptoscyphus (Lophocoleaceae) revisited. Taxon 59: 176-186.

VAN SLAGEREN M. W. 1985. A taxonomic monograph of the genera Brachiolejeunea and Frullanoides (Hepaticae), with a SEM analysis of the sporophyte in the Ptychanthoideae. Meded. Bot. Mus. Herb. Rijks Univ. Utrecht 544: 1-309.

VAN ZANTEN B. O. \& GRADSTEIN S. R. 1988. Experimental dispersal geography of Neotropical liverworts. Nova Hedwigia Beih. 90: 41-94.

von Konrat M., Söderström L., Renner M. A. M., HaGBORG A., BRISCOE L. \& ENGEL J. J. 2010. Early Land Plants Today (ELPT): how many liverwort species are there. Phytotaxa 9: 22-40.

WERnER F. \& GRADSTEIN S. R. 2009. Diversity of dry forest epiphytes along a gradient of human disturbance in the tropical Andes]. Journal of Vegetation Science 20: 59-68. 
Whittemore A. T. \& Allen B. 1996. The liverworts and hornworts of Belize. Bryologist 99: 64-67.

WigGinTON M. J. 2004. E. W. Jones's Liverwort and Hornwort Flora of West Africa. National Botanica Garden, Meise, Belgium.

Wigginton M. J. 2009. Checklist and distribution of the liverworts and hornworts of Sub-Saharan Africa, including the East African Islands, 3rd ed. Tropical Bryology Research Reports 8: 1-116.

WiLsOn R., Gradstein S. R., SCHNEIDER H. \& HEINRICHS J. 2007. Unravelling the phylogeny of Lejeuneaceae (Junger- manniopsida): evidence for four main lineages. Molec. Phylogenet. Evol. 43: 270-282.

YAMADA K. 1993. Taxonomic results of the BRYOTROP Expedition to Zaire and Rwanda. Trop. Bryol. 8: 127-130.

YAMADA K. \& GRADSTEIN S. R. 1991. The genus Radula (Hepaticae) in the Galapagos Islands. Trop. Bryol. 4: 63-68.

YUZAWA Y. 1991. A monograph of subgen. Chonanthelia of gen. Frullania (Hepaticae) of the World. J. Hattori Bot. Lab. 70: 181-291.

Received 23 March 2013

\section{APPENDIX 1}

Afro-Asiatic liverwort genera and species. Compilation based on Pócs $(1976,1992)$ and on a screening of the recent literature. Frullania apiculata (Reinw. et al.) Dumort. is listed as an Afro-Asiatic species, not as a pantropical species; neotropical material identified as $F$. apiculata (e.g., Gradstein \& Costa 2003; Gradstein \& Ilkiu-Borges 2009) differs from $F$. apiculata by its much smaller size and may be referred to $F$. exilis Taylor. The relationship between these two species needs further study.

GENERA: Acromastigum, Allisoniella, Conoscyphus, Cuspidatula, Gottschelia, Mastigophora, Notoscyphus, Plicanthus, Psiloclada, Ptychanthus, Symphyogynopsis, Wiesnerella.

SPECIES: Acrolejeunea aulacophora, A. pycnoclada, Acromastigum exile, Allisoniella nigra, Archilejeunea planiuscula, Asterella khasyana, Bazzania decrescens, B. praerupta, Calypogeia arguta, Cephaloziella kiaeri, Ceratolejeunea belangeriana, Cheilolejeunea decursiva, C. krakakammae, C. trapezia, C. ventricosa, Cololejeunea cuneata, C. falcata, C. furcilobulata, C. hasskarliana, C. inflectens, C. latilobula, C. peponiformis, C. peraffinis, C. planissima, C. platyneura, C. raduliloba, Colura mosenii, C. pluridentata, Conoscyphus trapezioides, Cuspidatula contracta, Cyathodium aureonitens, Denotarisia linguifolia, Drepanolejeunea pentadactyla, D. ternatensis, Fossombronia indica, Frullania apiculata, $F$. repandistipula, $F$. serrata, Gottschelia schizopleura, Harpalejeunea filicuspis, Herbertus dicranus, Heteroscyphus splendens, Lejeunea alata, L. anisophylla, L. helenae, L. papilionacea, L. tuberculosa, Lepidolejeunea bidentula, Leptolejeunea epiphylla, L. subdentata, L. vitrea, Mastigophora diclados, Notoscyphus lutescens, Plagiochasma appendiculatum, P. microcephalum, Pleurozia gigantea, Plicanthus birmensis, P. hirtellus, Porella madagascariensis, Psiloclada clandestina, Radula boryana, $R$. fulvifolia, $R$. madagascariensis, $R$. tabularis, Schiffneriolejeunea tumida, Symphyogynopsis gottscheana, Thysananthus spathulistipus, Wiesnerella denudata.

\section{APPENDIX 2}

Pantropical liverwort species (including species extending to temperate regions). Compilation based on a screening of the recent literature. Frullania apiculata is excluded here (see APPENDIX 1).

Anastrophyllum auritum, A. piligerum, Aneura pinguis, Anthelia juratzkana, Bazzania nitida, Blepharostoma trichophyllum, Calycularia crispula, Cephalozia bicuspidata, Cheilolejeunea intertexta, C. rigidula, C. trifaria, C. xanthocarpa, Chiloscyphus coadunatus, C. vermicularis, Cololejeunea cardiocarpa, C. hildebrandtii, C. minutissima, C. obliqua, C. truncatifolia, Colura tenuicornis, Cyathodium cavernarum, C. foetidissimum, Diplasiolejeunea cavifolia, D. cobrensis, D. rudolphiana, Dumortiera hirsuta, Frullania 
ericoides, F. nodulosa, F. obscura, F. riojaneirensis, Haplomitrium blumei, Lejeunea flava, Lepidozia reptans, Leptolejeunea elliptica, L. maculata, Lopholejeunea eulopha, L. nigricans, L. subfusca, Lophozia excisa, L. decolorans, Lunularia cruciata, Marchantia berteroana, M. paleacea, M. polymorpha, Marsupella emarginata, Metalejeunea cucullata, Metzgeria consanguinea, M. furcata, M. leptoneura, Pallavicinia lyellii,
Plagiochasma rupestre, Pycnolejeunea contigua, Reboulia hemisphaerica, Riccardia multifida, Riccia frostii, $R$. lamellosa, $R$. nigrella, $R$. sorocarpa, $R$. trichocarpa, $R$. cavernosa, $R$. crystallina, $R$. ciliata s.l., Ricciocarpos natans, Scapania cuspiduligera, Stictolejeunea balfourii, Solenostoma sphaerocarpa, Sphenolobus minutus, Syzygiella colorata, S. sonderi, Targionia hypophylla, Tritomaria exsecta 